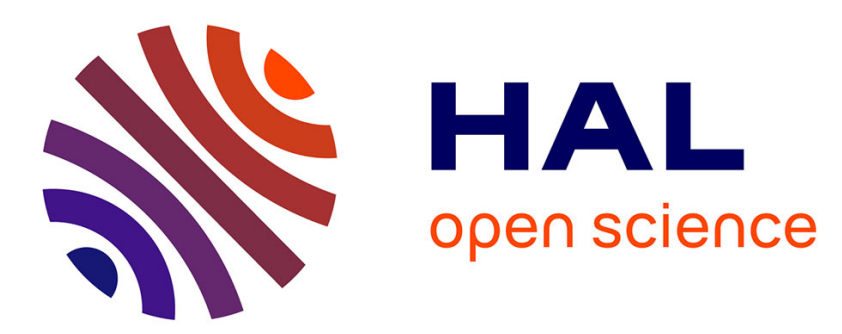

\title{
Rift zones and magma plumbing system of Piton de la Fournaise volcano: How do they differ from Hawaii and Etna?
}

Laurent Michon, Valérie Ferrazzini, Andrea Di Muro, Nicolas Villeneuve, Vincent Famin

\section{To cite this version:}

Laurent Michon, Valérie Ferrazzini, Andrea Di Muro, Nicolas Villeneuve, Vincent Famin. Rift zones and magma plumbing system of Piton de la Fournaise volcano: How do they differ from Hawaii and Etna?. Journal of Volcanology and Geothermal Research, 2015, 303, pp.112-129. 10.1016/j.jvolgeores.2015.07.031 . hal-01241283

\section{HAL Id: hal-01241283 \\ https: / hal.univ-reunion.fr/hal-01241283}

Submitted on 3 Nov 2016

HAL is a multi-disciplinary open access archive for the deposit and dissemination of scientific research documents, whether they are published or not. The documents may come from teaching and research institutions in France or abroad, or from public or private research centers.
L'archive ouverte pluridisciplinaire HAL, est destinée au dépôt et à la diffusion de documents scientifiques de niveau recherche, publiés ou non, émanant des établissements d'enseignement et de recherche français ou étrangers, des laboratoires publics ou privés. 


\title{
Review
}

\section{Rift zones and magma plumbing system of Piton de la Fournaise volcano: How do they differ from Hawaii and Etna?}

\author{
Laurent Michon $^{\mathrm{a}, *}$, Valérie Ferrazzini ${ }^{\mathrm{b}}$, Andrea Di Muro ${ }^{\mathrm{b}}$, Nicolas Villeneuve ${ }^{\mathrm{b}}$, Vincent Famin ${ }^{\mathrm{a}}$ \\ a Laboratoire GéoSciences Réunion, Université de La Réunion, Institut de Physique du Globe de Paris, Sorbonne Paris Cité, CNRS, F-97744 Saint Denis, France \\ b Observatoire Volcanologique du Piton de la Fournaise, Institut de Physique du Globe de Paris, Sorbonne Paris Cité, CNRS, Université Paris Diderot, F-75005 Paris, France
}

\begin{abstract}
A B S T R A C T
On ocean basaltic volcanoes, magma transfer to the surface proceeds by subvertical ascent from the mantle lithosphere through the oceanic crust and the volcanic edifice, possibly followed by lateral propagation along rift zones. We use a 19-year-long database of volcano-tectonic seismic events together with detailed mapping of the cinder cones and eruptive fissures to determine the geometry and the dynamics of the magma paths intersecting the edifice of Piton de la Fournaise volcano. We show that the overall plumbing system, from about $30 \mathrm{~km}$ depth to the surface, is composed of two structural levels that feed distinct types of rift zones.

The deep plumbing system is rooted between Piton des Neiges and Piton de la Fournaise volcanoes and has a N30-40 orientation. Above $20 \mathrm{~km}$ below sea level (bsl), the main axis switches to a N120 orientation, which permits magma transfer from the lithospheric mantle to the base of the oceanic crust, below the summit of Piton de la Fournaise. The related NW-SE rift zone is $15 \mathrm{~km}$ wide, linear, spotted by small to large pyroclastic cones and related lava flows and emits slightly alkaline magmas resulting from high-pressure fractionation of clinopyroxene \pm olivine. This rift zone has low magma production rate of $\sim 0.5-3.6 \times 10^{-3} \mathrm{~m}^{3} \mathrm{~s}^{-1}$ and an eruption periodicity of around 200 years over the last $30 \mathrm{ka}$. Seismic data suggest that the long-lasting activity of this rift zone result from regional NNE-SSW extension, which reactivates inherited lithospheric faults by the effect of underplating and/or thermal erosion of the mantle lithosphere.

The shallow plumbing system $(<11 \mathrm{~km} \mathrm{bsl})$ connects the base of the crust with the Central Cone. It is separated from the deep plumbing system by a relatively large aseismic zone between 8 and $11 \mathrm{~km}$ bsl, which may represent a deep storage level of magma. The shallow plumbing system feeds frequent, short-lived summit and flank (NE and SE flanks) eruptions along summit and outer rift zones, respectively. Summit rift zones are very active ( $\left.\sim 0.1-0.25 \mathrm{~m}^{3} \mathrm{~s}^{-1}\right)$, short $(2-3 \mathrm{~km})$, and present an orthogonal pattern confined to the central active cone of Piton de la Fournaise. Outer NE and SE rift zones are much less active $\left(\sim 4-7.3 \times 10^{-3} \mathrm{~m}^{3} \mathrm{~s}^{-1}\right)$ and extend from inside the Enclos Fouque caldera to bound the mobile eastern volcano flank. We show that the outer rift zones are almost aseismic and are genetically linked to the seaward flank displacements, whose most recent events where detected in 2004 and 2007. East flank sliding is itself triggered by shallow ( $<2 \mathrm{~km}$ depth) sill intrusions. We propose that the subvertical magma intrusions along the perpendicular summit rift zones, sill intrusions, and subsequent magma injections along the outer rift zones are controlled by cycles of stress permutations. We thus tentatively propose that as for Piton de la Fournaise, the regional stress field acting on Etna and Hawaiian volcanoes is an important parameter in the control of the magma transfer along their deep plumbing system whereas the dynamics of their summit system is governed by shallow stress variations (above $5-10 \mathrm{~km} \mathrm{bsl}$ ) due to edifice deformation and magma transfers.
\end{abstract}

\section{Contents}

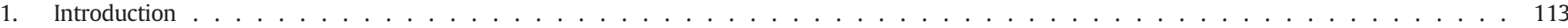

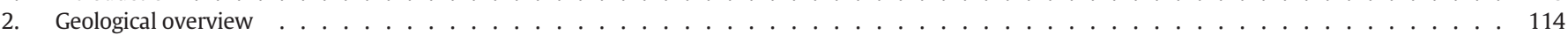

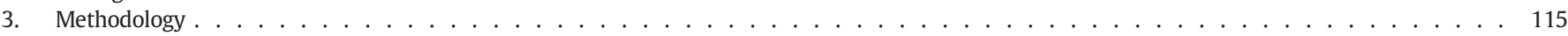

3.1. Cinder cones and magma volumes . . . . . . . . . . . . . . . . . . . . . . . . . . . . . . 115

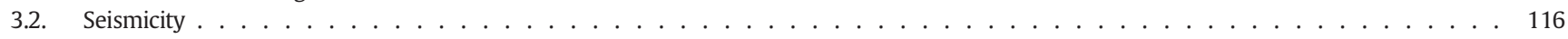

* Corresponding author.

E-mail address: laurent.michon@univ-reunion.fr (L. Michon). 


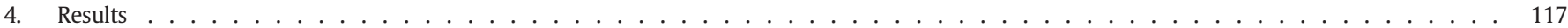

4.1. Rift zones distribution . . . . . . . . . . . . . . . . . . . . . . . . . . . 117

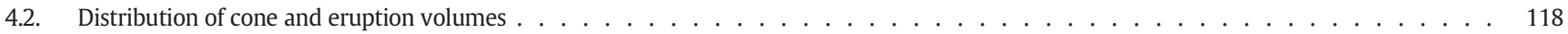

4.3. Magma extrusion rate . . . . . . . . . . . . . . . . . . . . . . . . . . . . 118

4.4. Geometry of the seismogenic zones . . . . . . . . . . . . . . . . . . . . . . . . . . . 119

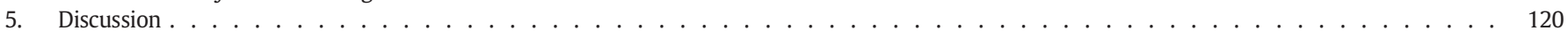

5.1. Geometry of the plumbing system . . . . . . . . . . . . . . . . . . . . . . . . . 120

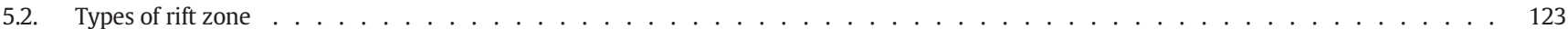

5.3. Origin and dynamics of the rift zones . . . . . . . . . . . . . . . . . . . . . . . . . . 124

5.3.1. NW-SE rift zone and South Volcanic Zone related to the deep plumbing system . . . . . . . . . . . . . . . . . 124

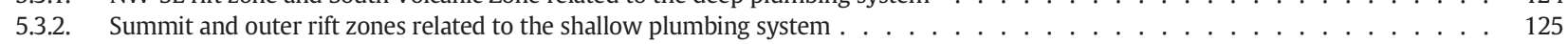

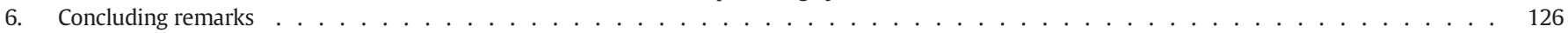

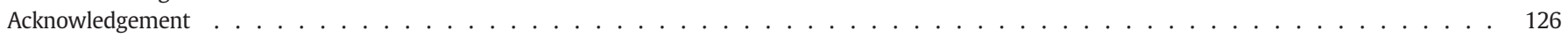

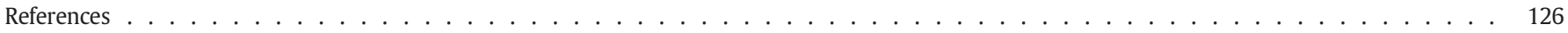

\section{Introduction}

On ocean basaltic volcanoes, magma transfer to the surface generally occurs along subvertical ascent paths from the mantle lithosphere through the oceanic crust and the volcanic edifice and is occasionally followed by lateral propagation along preferential intrusion paths termed "rift zones" (e.g. MacDonald, 1972). At the surface, rift zones manifest themselves by the localisation of cinder cones, pit craters, and eruptive fissures, which results from the long-term (millennia) eruptive history of the volcano. The wide range of their geometry, from radial or circumferential diffuse rift zones (e.g., Etna, Galapagos;
Chadwick and Dieterich, 1995; Neri et al., 2005) to narrow km-long rift zones (e.g., Hawaiian shields; Walker, 1999) is known to depend, among other parameters, on the dynamics of the plumbing system, the deformation of the volcanic edifice, and the structure of the crust underneath (MacDonald, 1972; Dieterich, 1988; Chadwick and Dieterich, 1995; Walker, 1999; Walter and Troll, 2003; Michon et al., 2007; Chaput et al., 2014a). For the world's most active basaltic volcanoes, such as Kilauea and Etna, the rift zones are well identified, correspond to the upper boundary of flank displacements (Fig. 1a and b), and are dynamically linked to this deformation (Dieterich, 1988; Acocella and Neri, 2003; Neri et al., 2005; Walter et al., 2005a;
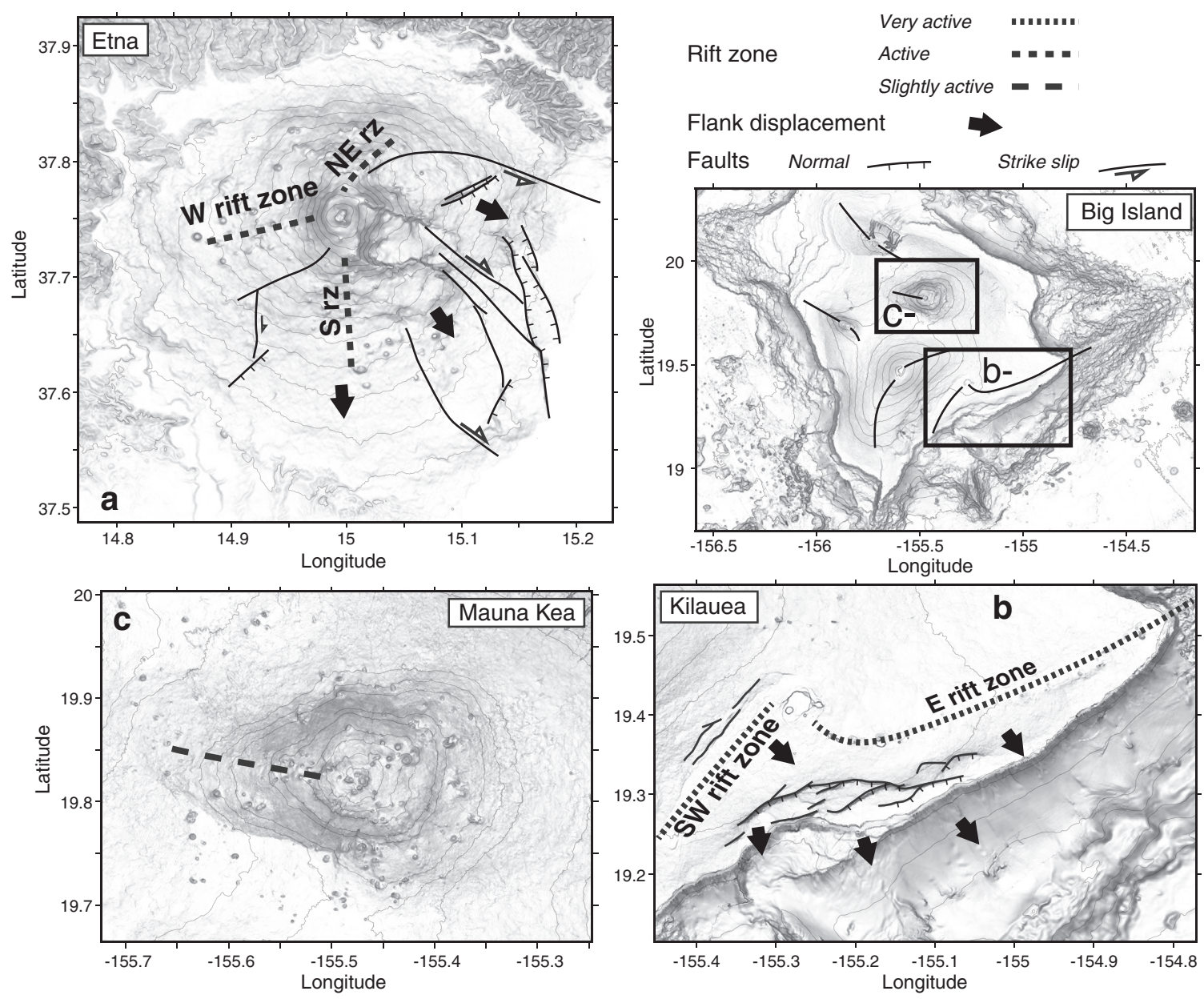

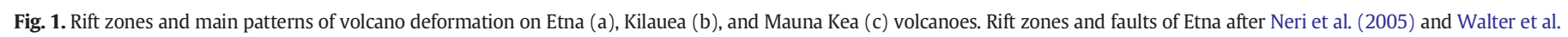
(2005b). Rift zones of Hawaii after McDonald (1972) and Lipman et al. (2006). 
Montgomery-Brown et al., 2011). When the activity rate drops down, the rift zones enlarge and become characterised by scattered, less frequent cone-forming eruptions, a typical product of late postshield activity like at Hualalai and Mauna Kea volcanoes in Hawaii (Fig. 1c; Clague, 1987; Peterson and Moore, 1987; Wolfe et al., 1997; Clague and Sherrod, 2014). Rift zones are thus highly sensitive to the interrelation between magma production rate, magnitude of flank displacements, and dynamics of the volcano plumbing system.

At Piton de la Fournaise shield volcano (La Réunion hotspot), the geometry of the rift zones is still debated (Chevallier and Bachèlery, 1981; Michon et al., 2007; Bonali et al., 2011) and only the "shallow part" of its plumbing system has been imaged down to $5-11.5 \mathrm{~km}$ below the summit (Battaglia et al., 2005a; Massin et al., 2011; Lénat et al., 2012; Di Muro et al., 2014). However, recent volcanic and seismic activity is widespread on the volcano flanks. Understanding the link between rift zone development, the dynamics of the plumbing system, and the structure of the plumbing system at depth requires a precise characterisation of the geometry of the rift zones and of their dynamics.

We here aim at quantifying the geometry and the activity (seismic, volcanic) of the rift zones of Piton de la Fournaise in order to improve our understanding of the plumbing system. Constraining the geometry of the plumbing system at the scale of the whole edifice is critical to understand the link between deep magma transfer/storage and the phases of quiescence, reactivation, and fluctuations of the volcanic activity of Piton de la Fournaise (Roult et al., 2012). In the following, we constrain the rift zone geometry and activity at the edifice scale by performing a new mapping of the spatial and volume distribution of the 644 pyroclastic cones. Determination of the rift zones in the Enclos Fouqué caldera is further constrained by the analysis of distribution of the eruptive fissures formed between 1972 and 2014. The geometry of the plumbing system is inferred from the spatial distribution of the hypocenters related to 8465 volcano-tectonic seismic events recorded by the Observatoire Volcanologique du Piton de la Fournaise (OVPF/ IPGP) between 1996 and 2014.

\section{Geological overview}

La Réunion is a 5 Ma old basaltic volcanic edifice whose current subaerial part is composed of Piton des Neiges volcano (3.1 km high above sea level), inactive since its last trachytic eruptions about $30 \mathrm{ka}$ ago (Salvany et al., 2012), and Piton de la Fournaise volcano (2.6 km high above sea level), active since at least $0.53 \mathrm{Ma}$ (Gillot and Nativel, 1989; Fig. 2a). The historical activity of Piton de la Fournaise is mostly restricted to the Enclos Fouqué caldera (97\% of the post 1708 CE eruptions) and rarely propagated along the well-identified NE and SE rift zones (Villeneuve and Bachèlery, 2006; Michon et al., 2013; Fig. 2b). Volcano monitoring since 1980 has permitted to relate modern volcanic activity to a relatively shallow plumbing system located below the Central Cone, and imaged by the pre- and post-eruptive seismicity down to $8 \mathrm{~km}$ below sea level (10.6 km below volcano summit; Battaglia et al., 2005a; Prôno et al., 2009; Massin et al., 2011). Magmas emitted by this central plumbing system vary from aphyric transitional basalts named steady-state basalts (SSB; Albarède et al., 1997) to olivine-rich basalts known as oceanites (Lacroix, 1936), both resulting from a shallow fractionation/accumulation of forsterite followed by clinopyroxene and plagioclase after deep crystallisation of pyroxene (Albarède et al., 1997; Famin et al., 2009; Di Muro et al., 2014).

Besides this very active part ( 1 eruption/9 months, on average), an "eccentric" activity, defined as located West of the Enclos Fouqué and the NE and SE rift zones (Lénat et al., 2012) was described along less active rift zones (Bachèlery, 1981; Villeneuve and Bachèlery, 2006; Bonali et al., 2011). The main structure is outlined by scattered scoria cones along a NW-SE axis connecting the summits of Piton des Neiges and Piton de la Fournaise ("Plaine des Cafres"; Fig. 2b). A secondary volcanic alignment parallel to the main NW-SE rift zone, evidenced by scoria cones (the South Volcanic Zone on Fig. 3), is developed on the southwestern coast of Piton de la Fournaise. Scoria cones and eruptive fissures permit to identify two further rift zones on the NE and SE volcano flank. Activity of NE and SE rifts is well documented since human settlement in 1640 CE on the island (Michon et al., 2013). Only 7 eruptions have been observed along these rift zones. Eruptions occurred during the
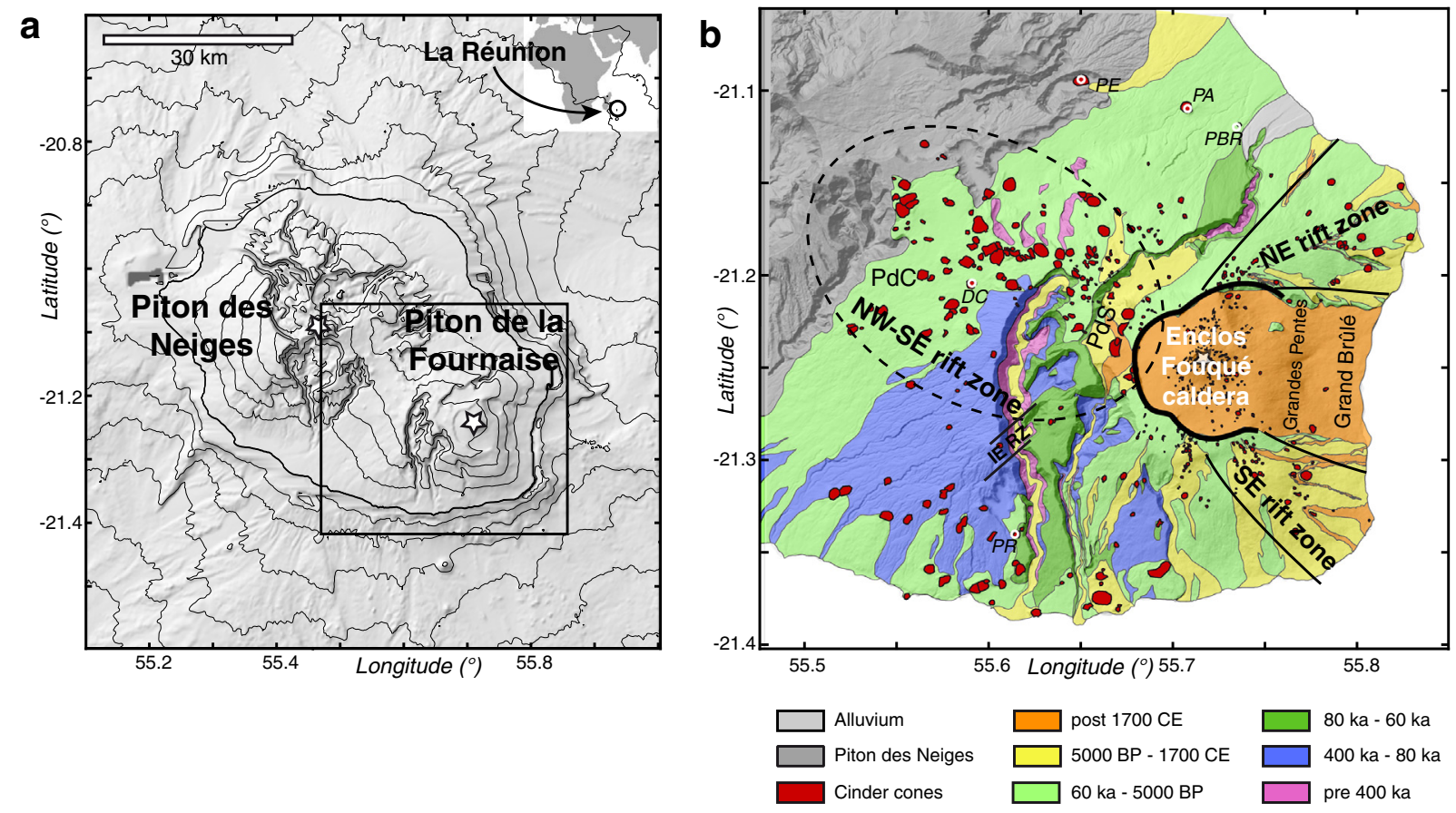

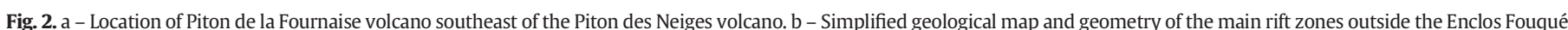

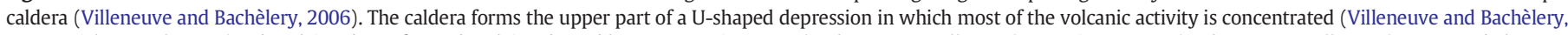

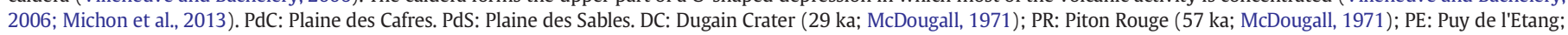
PA: Piton Armand; PBR: Piton Belle Rive. IERZ: Ilet Edouard rift zone. 

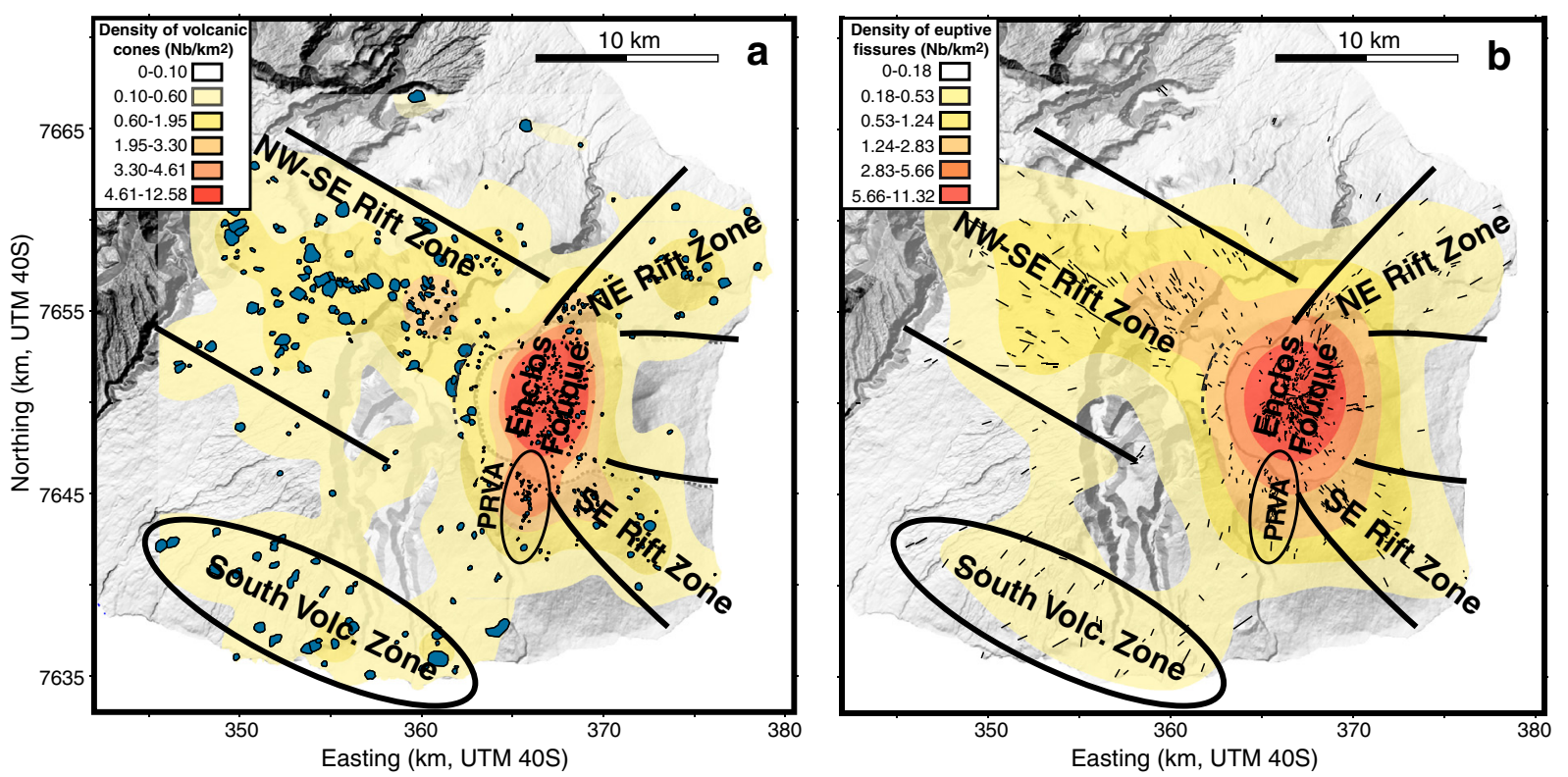

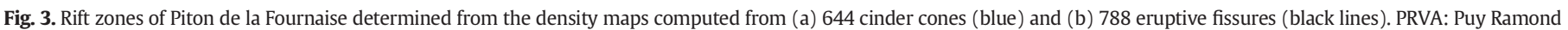
volcanic alignment. The dashed lines highlight cones organised concentrically around the western rim of the Enclos Fouqué caldera.

18th (4 eruptions) and 20th ( 3 eruptions) centuries with a pause of 177 years between 1800 and 1977 (Michon et al., 2013). Beside this "historical" activity, the long-term age distribution of the flank activity (including the NE, SE, and NW-SE rift zones and the South Volcanic Zone) is poorly constrained. Along the NW-SE rift zone, the activity started at least $29 \mathrm{ka}$ ago (Dugain crater along the NW-SE rift zone, Fig. 2b; McDougall, 1971), the most recent eruptions in this sector occurred in the 14th-17th centuries for an average eruption frequency of one eruption every 200 years during the last $2 \mathrm{ka}$ (Morandi et al., in press). In the sectors of the NE and SE rift zones, geochronological data do not allow identifying eruptions older than the 14th (Morandi et al., in press), which is a minimum age considering the slightly degraded morphology of several cinder cones.

Interestingly, magma composition along this main NW-SE rift zone differs from those emitted in the Enclos Fouqué caldera and on the NE and SE rift zones (Lénat et al., 2012). Magmas erupted along the NW-SE rift zone are MgO rich and have higher K and lower Ca concentrations with respect to centrally erupted magmas. This difference has been considered to result from high-pressure (>0.4 GPa) fractionation of clinopyroxene and olivine (Kornprobst et al., 1984; Albarède et al., 1997) and possibly plagioclase (Famin et al., 2009). Moreover, fluid and melt inclusions suggest that magma storage below the NW-SE rift zone occurs at higher pressure than below the central system (Bureau et al., 1998a, 1998b). Only rare events with this signature have occurred inside the Enclos Fouqué caldera (e.g. Hudson eruption in 1998; Bureau et al., 1999) and have been preceded by an unusually deep seismicity partly located along the NW-SE rift zone (Battaglia et al., 2005a).

\section{Methodology}

\subsection{Cinder cones and magma volumes}

Geological maps and a 25-m step digital elevation model (DEM) enabled to map a total of 644 cinder cones mostly built on surfaces younger than $60 \mathrm{ka}$ (Fig. 3). In the Enclos Fouqué caldera, the amount of cinder cones is minimised due to either the small size of the structures or the high resurfacing rate in the northern, eastern, and southern parts of this area.

We first quantified the footprint area $A_{c o}$ of each cone (considering their base as delimited by the break in slope between the cone and the basement) and then we calculated their volume $C V$ using two complementary procedures in order to validate the results.

In the first procedure, we directly determined the volume $C V$ of 231 cones by subtracting the topography located below a certain level taken as the base of the edifices, following the same procedure as Guilbaud et al. (2012). This dataset made of the cone footprint $A_{C o}$ and $C V$ shows a clear power-law relationship between the planar surface and the volume of each cone over 3 and 5 orders of magnitude for $A_{c o}$ and $C V$, respectively (Fig. 4a). This relationship was then used to quantify $C V$ for the entire dataset.

In the second procedure, classical morphometric relationships were used (Porter, 1972; Wood, 1980; Riedel et al., 2003). The volume of a cinder cone can be determined from its footprint $A_{c o}$, simplifying the actual geometry to ideal symmetrical cone with circular bases of diameter $W_{c o}=\left(4 A_{c o} / \pi\right)^{0.5}$. According to Riedel at al. (2003) and Kervyn et al. (2012), $C V$ can be expressed as $C V=11.31 H_{c o}, H_{c o}$ being the cone's height. The link between $W_{c o}$ and $H_{c o}$ has long been taken as $H_{c o} / W_{c o}=$ 0.18 (Porter, 1972; Wood, 1980). However, average values of $H_{c o} / W_{c o}$ as different as $0.11,0.12,0.137$, and 0.152 have been recently determined for the cone fields of Mauna Kea, Lanzarote, Etna, and Tenerife volcanoes, respectively (Favalli et al., 2009; Kervyn et al., 2012; Kereszturi et al., 2013a). Given these variations of $H_{c o} / W_{c o}$, we calibrated this ratio for Piton de la Fournaise, expressed as $H_{c o} / W_{c o}=(C V / 11.31)^{1 / 3} /$ $\left(4 A_{c o} / \pi\right)^{1 / 2}$, from the 231 cones of Piton de la Fournaise mapped in the first procedure. The mean $H_{c o} W_{c o}$ of 0.135 , in very good agreement with the one obtained in Hawaii, Etna, and Canaries (Favalli et al., 2009; Kervyn et al., 2012; Kereszturi et al., 2013a), was then considered to determine $C V$ for all the 644 cinder cones of Piton de la Fournaise.

The volume $C V$ calculated from the second procedure showing values systematically $10 \%$ larger than the ones obtained with the first procedure, mean values of both procedures were finally considered.

Quantification of the volume of a cinder cone allows assessing that of the associated lava flow. Indeed, Wood (1980) showed from 35 eruptions from 6 distinct basaltic volcanoes that the volume of a cinder cone and the associated lava flow are linked by a power-law relationship. We used 123 eruptions that occurred on Piton de la Fournaise to improve this correlation (Fig. 4). Bulk volume estimates for recent lava flows (Krafft and Gérente, 1977a, 1977b; Bachèlery et al., 1982; Lénat et al., 1989; Roult et al., 2012) were correlated to the cone's volumes determined from the DEM, following the methodology described above. The correlation was further constrained for the largest cone volumes 

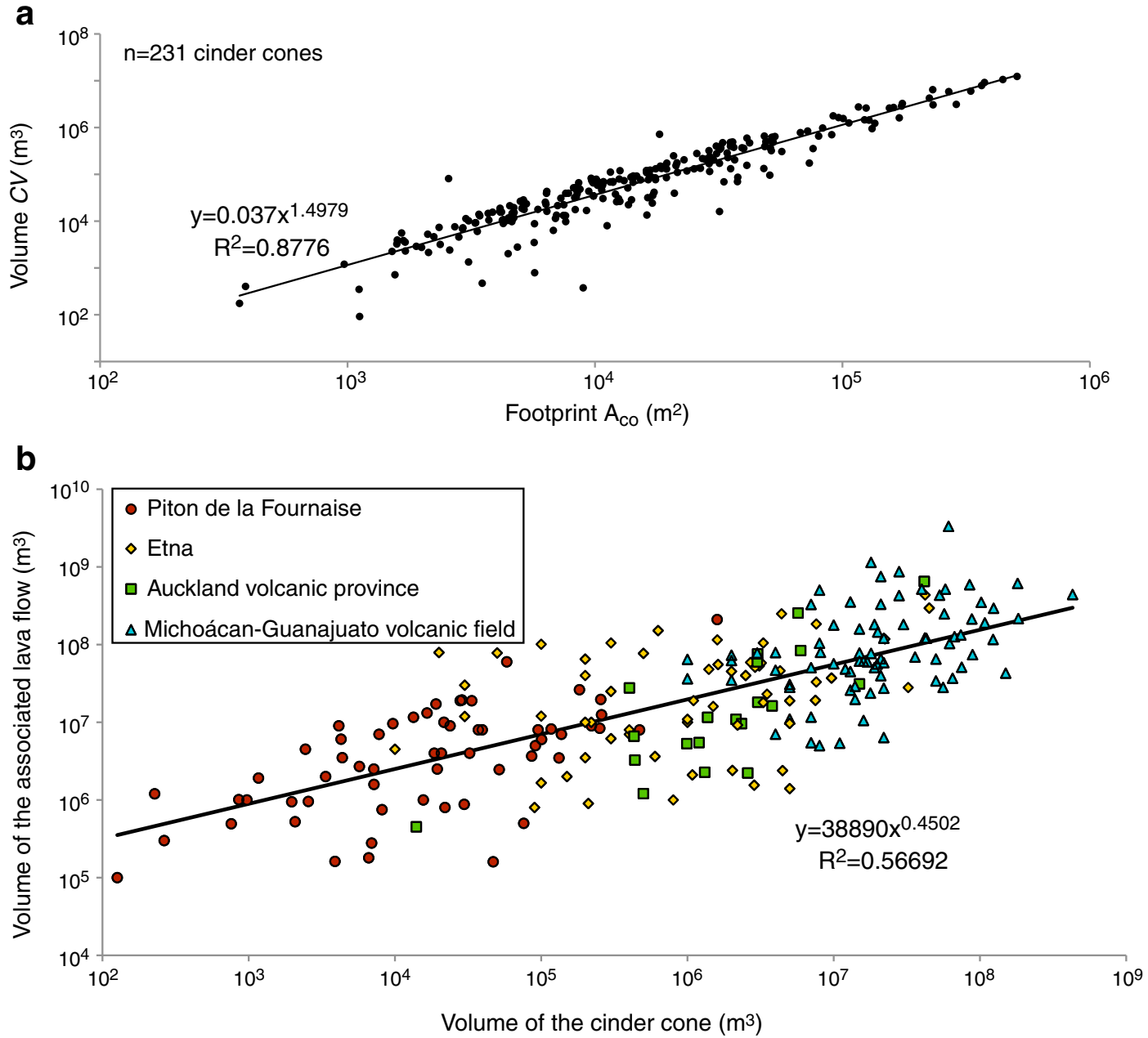

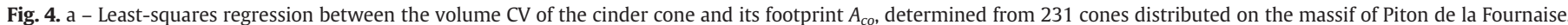

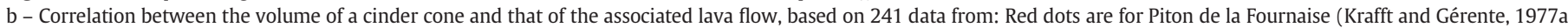

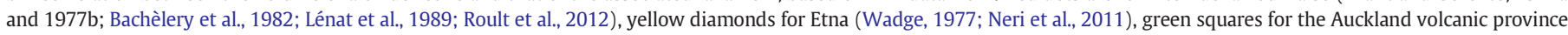
(Kereszturi et al., 2013b), and blue triangles are for the Michoácan-Guanajuato volcanic field (Guilbaud et al., 2012).

encountered at Piton de la Fournaise by data of Etna (Wadge, 1977; Neri et al., 2011), the Auckland volcanic province (Kereszturi et al., 2013b), and the Michoácan-Guanajuato volcanic field (Guilbaud et al., 2012). The overall dataset (Fig. 4) provides estimates of the volume of a lava flow $F V$ related to the cone-forming eruption and of the magma emitted along the different rift zones of Piton de la Fournaise.

\subsection{Seismicity}

Between 1996 and 2014, the seismological network of OVPF recorded a wide range of seismic signals. They mostly correspond to i) highfrequency earthquakes, also called volcano-tectonic (VT) events (Battaglia et al., 2005a; Massin et al., 2011); ii) volcanic tremors during (Battaglia et al., 2005b) and only seldom before the eruptive phases (Roult et al., 2012); and, to a lesser extent, iii) low-frequency events resulting from either magma and fluid transfer below the summit (Aki and Ferrazzini, 2000; Battaglia and Aki, 2003; Zecevic et al., 2013) or rockfalls, especially frequent since the Dolomieu caldera collapse in 2007 (Aki and Ferrazzini, 2000; Hibert et al., 2011). Here, we focus on the VT events whose origin can be attributed to a very large range of processes ranging from magma intrusion during dyke or sill propagation, withdrawal of the volcanic plumbing system, regional tectonic forces, gravitational loading, pore pressure effects, and hydrofracturing (Moran, 2003; Patanè et al., 2004; McNutt, 2005; Wright and Klein, 2006).
During the19-year-long period spanning between 1996 and 2014, a total of 8465 VT events has been recorded and manually located by the OVPF staff (Fig. 5a). Out of these events, 8193 occurred below the massif of Piton de la Fournaise (Fig. 5b). The seismic network of OVPF allows locating events having a magnitude of duration of at least Md 1. As a whole, VT events recorded are weak; the strongest event (Md 3.6) was recorded during the April 2007 caldera collapse. In the OVPF catalogue, $90 \%$ of the VT events have magnitude between 1 and 1.7, making Piton de la Fournaise a less seismogenic volcano than Etna or Hawaiian volcanoes (Wright and Klein, 2006; Sicali et al., 2014). Earthquake location is computed using handpicked $\mathrm{P}$ and $\mathrm{S}$ phase time on vertical and horizontal components, respectively. The software HYPO71 (Lee and Lahr, 1975), modified by Nercessian et al. (1996) to take into account the station elevation along the ray, has been used to determine their hypocentres using a 1-D velocity model composed of eight horizontal layers, which has been developed for routine hypocentre determination at the observatory. The input velocity ratio is the same as in other studies on Piton de la Fournaise (Hirn et al., 1991; Nercessian et al., 1996; Battaglia et al., 2005a; Massin et al., 2011). The densification of the seismic network around the volcano's summit and on the whole island since 2009 enabled to improve the determination of earthquake hypocentres. Despite these efforts, the vertical and horizontal errors of each event increase from $200 \mathrm{~m}$ close to the volcano's summit (Massin et al., 2011), where the network is densest, to several kilometres in the rest of the study area. In consequence, we solely 

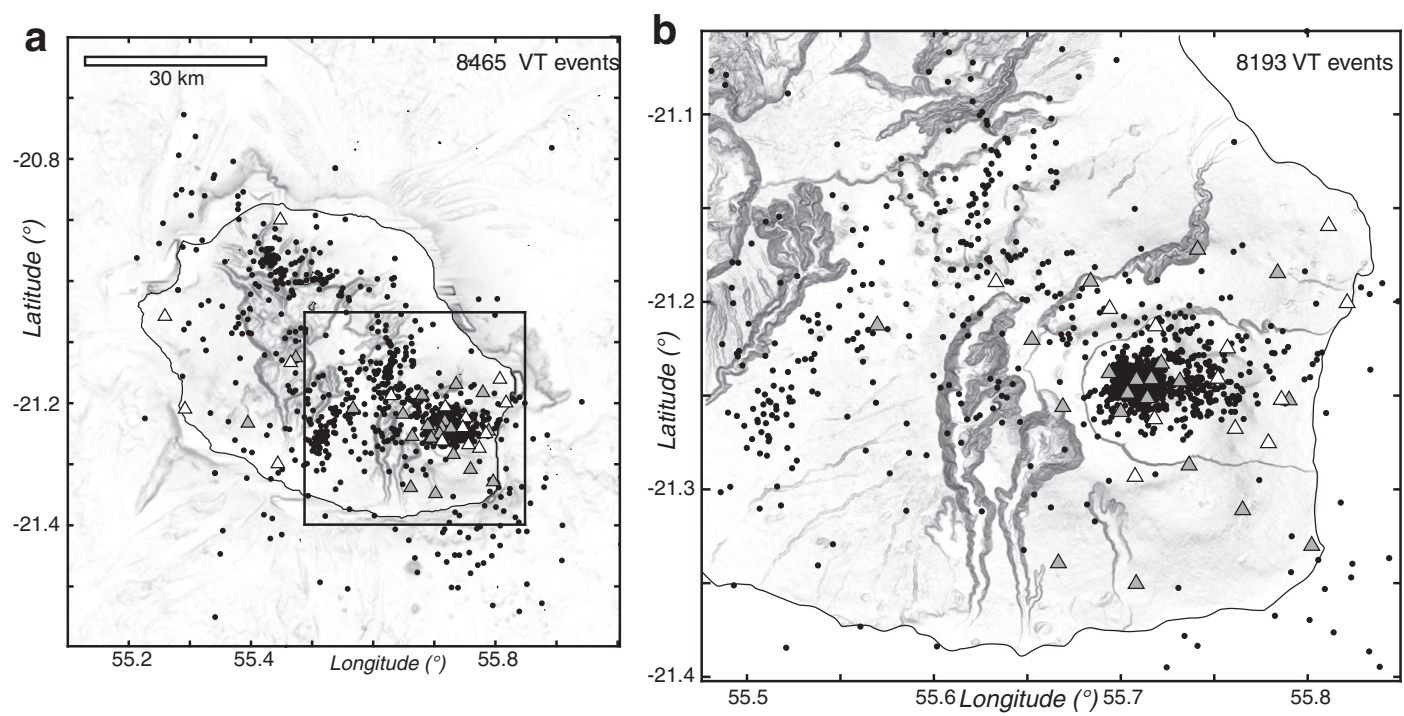

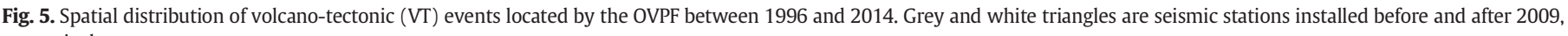
respectively.

consider in this work the clusters of earthquakes and do not interpret the widely scattered events (Fig. 5).

\section{Results}

\subsection{Rift zones distribution}

Groups of eruptive fissures, pit craters, and cinder cones combine to delineate rift zones (Walker, 1999). Consequently, our density maps calculated from 644 cinder cones and 788 eruptive fissures on the massif of Piton de la Fournaise give insights into the distribution of preferential intrusion paths and the related rift zones (Fig. 3). The densest cone and fissure concentrations occur inside the Enclos Fouqué caldera, where most of the cinder cones ( 287 cones, about $45 \%$ of the total dataset) draw an overall $\mathrm{N}-\mathrm{S}$ elongated zone centred on the active Central Cone. In the Enclos Fouqué, the location of the eruptive sites and their related eruptive fissures and cones allow refining the rift zone distribution. For the period spanning between 1972 and 2014, 82 eruptions occurred or started inside the Enclos Fouqué caldera (Table 1). The distribution of the eruptive fissures reveals that the majority of the dykes (59 out of 82) intruded the Central Cone along two main trends (N25-30 and N120) identified by Michon et al. (2007, 2013). Extensometer and inclinometer data suggest that these eruptive events are first characterised by a magma vertical ascent rooted at about sea level below the western limit of Dolomieu crater, possibly followed by a limited lateral dyke propagation (Peltier et al., 2007), which usually stops before or at the base of the Central Cone. The resulting edifice deformation is restricted to the Central Cone (Fukushima et al., 2005; Peltier et al., 2008; Michon et al., 2009; Got et al., 2013). Only during a few events (November 1987, September 1988, and November 2002), the dykes propagated 1-2 km away from the base of the cone. In the same period, 23 eruptions started directly on the floor of the Enclos Fouqué caldera and occasionally propagated downslope outside the Enclos Fouqué caldera following the NE (in 1977, 1998) and SE (1986) directions or along the northern (in 2002, 2005) and southern (in 1976, 2007) walls of the Grandes Pentes and Grand Brûle (Table 1; Fig. 6). Beside the difference of location of the first eruptive fissure, i.e. in the Central Cone for the summit or on the Enclos Fouqué floor for the flank eruptions, deformation data thus suggest a different magma path for flank eruptions with a vertical ascent below the eastern rim of the Dolomieu and large displacements of the eastern flank (Peltier et al., 2008; Michon et al., 2009; Got et al., 2013). The downslope propagation of the active eruptive fissures along the NE and SE rift zone suggests that magma migration mostly occurs laterally along these intrusion paths. Interestingly, the eruptive fissures related to the flank eruptions are concentrated in three areas located south, east, and north of the Central Cone. They define three rift zones, called here "outer rift zones": a southeast, an east, and a north-east rift zone gathering 12, 4, and 7 distal eruptions, respectively (Fig. 6). The location and spatial evolution of eruptive vents suggest that these outer rift zones are spatially disconnected from the N25-30 and N120 alignments ("summit rift zones"). The different paths followed by the ascending magma and the different deformation patterns associated with summit and flank eruptions support such a disconnection. In summary, our analysis of recent eruption distribution indicates that two groups of preferential directions can be identified inside the Enclos Fouqué caldera on the base of cone and dyke distribution: the N25-30 and N120 "summit rift zones," which feed summit eruptions of the Central Cone and the "outer rift zones" along which flank eruptions occur. The cone distribution delineates the continuity of the SE and NE outer rift zones outside the Enclos Fouqué caldera and the N10 trending Puy Ramond volcanic alignment (Fig. 3), which seems to be spatially linked to the SE rift zone (Chevallier and Bachèlery, 1981; Villeneuve and Bachèlery, 2006; Bonali et al., 2011).

West and south-west of the Enclos Fouqué caldera, cinder cones called "eccentric cones" by Lénat et al. (2012) are concentrated along two N120 trending axes. The main one is located between the summit of Piton de la Fournaise and the dormant Piton des Neiges volcano and a second one occurs along the south-western coast of Piton de la Fournaise (Fig. 3). The former, outlined by 161 cinder cones, draws the well-identified 20-km-long and 12-km-wide NE-SW rift zone (Chevallier and Bachèlery, 1981; Villeneuve and Bachèlery, 2006), while the latter, named the South Volcanic Zone, is delineated by 28 cones widely spread over the 20 -km-long and 8 -km-wide volcanic area. In this south-western area, seven cones built on lava flows older than $290 \mathrm{ka}$ (McDougall, 1971; Fig. 2b) and presenting high degradation states were considered as associated with the $>60$-ka-old Ilet Edouard rift zone and consequently not integrated to the SVZ. These cones disregarded, the wide range of degradation states of the cinder cones related to the South Volcanic Zone and the NW-SE rift zone (from stages 5 -fresh- to 3 -incised by gullies- in Colton's classification; Colton, 1967) suggests a long-term volcanic activity along these two axes. Besides a clear cone concentration, the NW-SE rift zone is also outlined by the occurrence of pit craters aligned on N100-N140 trending eruptive fissures (Villeneuve and Bachèlery, 2006). Finally, less than $2 \%$ of the cones found on the massif of Piton de la Fournaise occurred outside 
Table 1

Eruptions of Piton de la Fournaise between 1972 and 2014.

\begin{tabular}{|c|c|c|c|c|}
\hline \multicolumn{2}{|c|}{ Eruption timing } & \multirow{2}{*}{$\begin{array}{l}\text { Eruption } \\
\text { type }\end{array}$} & \multirow[t]{2}{*}{ Rift zone } & \multirow{2}{*}{$\begin{array}{l}\text { Volume } \\
\left(106 \mathrm{~m}^{3}\right)\end{array}$} \\
\hline $\begin{array}{l}\text { Start } \\
\text { (dd/mm/yy) }\end{array}$ & $\begin{array}{l}\text { End } \\
(\mathrm{dd} / \mathrm{mm} / \mathrm{yy})\end{array}$ & & & \\
\hline 6/9/1972 & 6/11/1972 & Summit & $\mathrm{N} 25-30 \mathrm{RZ}$ & 0.27 \\
\hline 7/25/1972 & 8/17/1972 & Flank & East RZ & 2.9 \\
\hline 9/7/1972 & 9/26/1972 & Summit & N25-30 RZ & 4 \\
\hline $10 / 10 / 1972$ & $12 / 10 / 1972$ & Flank & South-east RZ & 9.3 \\
\hline 5/10/1973 & $5 / 28 / 1973$ & Summit & N120 RZ & 1.6 \\
\hline $11 / 4 / 1975$ & $11 / 18 / 1975$ & Summit & N120 RZ & 1.4 \\
\hline $12 / 18 / 1975$ & 1/25/1976 & Summit & N120 RZ & 0.03 \\
\hline $1 / 12 / 1976$ & $4 / 6 / 1976$ & Flank & South-east RZ & 11.6 \\
\hline $11 / 2 / 1976$ & $11 / 3 / 1976$ & Summit & N25-30 RZ & 0.46 \\
\hline $3 / 24 / 1977$ & $3 / 24 / 1977$ & Flank & South-east RZ & 0.06 \\
\hline $4 / 5 / 1977$ & 4/16/1977 & Flank & North-east RZ & 20 \\
\hline $10 / 24 / 1977$ & $11 / 17 / 1977$ & Summit & N120 RZ & 23 \\
\hline 5/28/1979 & 5/29/1979 & Summit & N25-30 RZ & 0.2 \\
\hline 7/13/1979 & 7/14/1979 & Summit & $\mathrm{N} 25-30 \mathrm{RZ}$ & 0.3 \\
\hline $2 / 3 / 1981$ & $2 / 24 / 1981$ & Summit & $\mathrm{N} 25-30 \mathrm{RZ}$ & 3 \\
\hline $2 / 24 / 1981$ & 3/31/1981 & Summit & $\mathrm{N} 25-30 \mathrm{RZ}$ & 4 \\
\hline 4/1/1981 & $5 / 5 / 1981$ & Flank & East RZ & 5 \\
\hline $12 / 4 / 1983$ & $1 / 18 / 1984$ & Summit & N25-30 RZ & 8 \\
\hline $1 / 18 / 1984$ & $2 / 18 / 1984$ & Summit & N25-30 RZ & 9 \\
\hline $6 / 14 / 1985$ & $6 / 15 / 1985$ & Summit & N25-30 RZ & 1 \\
\hline $8 / 5 / 1985$ & $9 / 1 / 1985$ & Summit & N25-30 RZ & 7 \\
\hline 9/6/1985 & $10 / 10 / 1985$ & Summit & N120 RZ & 14 \\
\hline 12/1/1985 & 12/3/1985 & Summit & $\mathrm{N} 25-30 \mathrm{RZ}$ & 0.7 \\
\hline $12 / 29 / 1985$ & 2/7/1986 & Summit & N120 RZ & 7 \\
\hline 3/19/1986 & $4 / 5 / 1986$ & Flank & South-east RZ & 13.5 \\
\hline 7/13/1986 & 7/13/1986 & Summit & N120 RZ & 0.28 \\
\hline $11 / 12 / 1986$ & $11 / 13 / 1986$ & Summit & N120 RZ & 0.27 \\
\hline $11 / 26 / 1986$ & $11 / 27 / 1986$ & Summit & N120 RZ & 0.24 \\
\hline $12 / 6 / 1986$ & 1/7/1987 & Summit & N120 RZ & 2 \\
\hline $1 / 7 / 1987$ & $2 / 10 / 1987$ & Flank & East RZ & 10 \\
\hline $6 / 10 / 1987$ & $6 / 29 / 1987$ & Summit & N120 RZ & 1 \\
\hline 7/19/1987 & $7 / 20 / 1987$ & Flank & East and South RZ & 1 \\
\hline $11 / 6 / 1987$ & $11 / 8 / 1987$ & Summit & $\mathrm{N} 25-30 \mathrm{RZ}$ & 1.6 \\
\hline $11 / 30 / 1987$ & $1 / 1 / 1988$ & Flank & South-east RZ & 10 \\
\hline 2/7/1988 & $4 / 2 / 1988$ & Flank & South-east RZ & 8 \\
\hline $5 / 18 / 1988$ & $8 / 1 / 1988$ & Summit & N25-30 RZ & 7 \\
\hline $8 / 31 / 1988$ & 9/12/1988 & Summit & N25-30 RZ & 4 \\
\hline $12 / 14 / 1988$ & $12 / 29 / 1988$ & Flank & North-east RZ & 4 \\
\hline $1 / 18 / 1990$ & 1/19/1990 & Summit & N120 RZ & 0.97 \\
\hline $4 / 18 / 1990$ & $5 / 8 / 1990$ & Flank & South-east RZ & 8 \\
\hline 7/19/1991 & $7 / 20 / 1991$ & Summit & N120 RZ & 5 \\
\hline 8/27/1992 & 9/23/1992 & Summit & N120 RZ & 5.5 \\
\hline $3 / 9 / 1998$ & $9 / 21 / 1998$ & Summit & $\mathrm{N} 25-30 \mathrm{RZ}$ & 60 \\
\hline 3/11/1998 & 4/1/1998 & Other & NW-SE RZ & 0.75 \\
\hline 8/8/1998 & $9 / 15 / 1998$ & Flank & North-east RZ & 0.9 \\
\hline 7/19/1999 & 7/31/1999 & Summit & N120 RZ & 1.3 \\
\hline 9/28/1999 & $10 / 23 / 1999$ & Summit & N25-30 RZ & 1.4 \\
\hline $2 / 13 / 2000$ & $3 / 3 / 2000$ & Summit & N25-30 RZ & 8.2 \\
\hline $6 / 23 / 2000$ & $7 / 30 / 2000$ & Flank & South-east RZ & 10 \\
\hline $10 / 12 / 2000$ & $11 / 13 / 2000$ & Summit & N120 RZ & 9 \\
\hline $3 / 27 / 2001$ & $4 / 4 / 2001$ & Summit & N120 RZ & 4.8 \\
\hline $6 / 11 / 2001$ & $7 / 9 / 2001$ & Summit & N120 RZ & 9.5 \\
\hline $1 / 5 / 2002$ & $1 / 16 / 2002$ & Flank & North-east RZ & 13 \\
\hline $11 / 16 / 2002$ & $12 / 3 / 2002$ & Summit & N120 RZ & 8 \\
\hline $5 / 30 / 2003$ & $5 / 30 / 2003$ & Summit & N25-30 RZ & 0.16 \\
\hline $6 / 4 / 2003$ & 6/9/2003 & Summit & $\mathrm{N} 25-30 \mathrm{RZ}$ & 0.72 \\
\hline $6 / 12 / 2003$ & $6 / 15 / 2003$ & Summit & N25-30 RZ & 0.59 \\
\hline $6 / 22 / 2003$ & $7 / 7 / 2003$ & Summit & N25-30 RZ & 0.69 \\
\hline $8 / 22 / 2003$ & $8 / 27 / 2003$ & Summit & $\mathrm{N} 25-30 \mathrm{RZ}$ & 6.2 \\
\hline $9 / 30 / 2003$ & $10 / 1 / 2003$ & Summit & $\mathrm{N} 25-30 \mathrm{RZ}$ & 1 \\
\hline $12 / 7 / 2003$ & $12 / 25 / 2003$ & Summit & N120 RZ & 1.2 \\
\hline $1 / 8 / 2004$ & $1 / 8 / 2004$ & Flank & North-east RZ & 1.9 \\
\hline $5 / 2 / 2004$ & $5 / 18 / 2004$ & Summit & N25-30 RZ & 16.9 \\
\hline $8 / 12 / 2004$ & $10 / 16 / 2004$ & Summit & N120 RZ & 20 \\
\hline $2 / 17 / 2005$ & $2 / 26 / 2005$ & Flank & North-east RZ & 19 \\
\hline $10 / 4 / 2005$ & $10 / 17 / 2005$ & Summit & N25-30 RZ & 2 \\
\hline $11 / 29 / 2005$ & $11 / 29 / 2005$ & Summit & N25-30 RZ & 1 \\
\hline $12 / 26 / 2005$ & $1 / 18 / 2006$ & Flank & North-east RZ & 20 \\
\hline $7 / 20 / 2006$ & $8 / 14 / 2006$ & Summit & $\mathrm{N} 25-30 \mathrm{RZ}$ & 2 \\
\hline $8 / 30 / 2006$ & $1 / 1 / 2007$ & Summit & N120 RZ & 20 \\
\hline $2 / 18 / 2007$ & $2 / 19 / 2007$ & Summit & N120 RZ & 1 \\
\hline $3 / 30 / 2007$ & $3 / 31 / 2007$ & Flank & South-east RZ & 0.6 \\
\hline $4 / 2 / 2007$ & $5 / 1 / 2007$ & Flank & South-east RZ & 240 \\
\hline
\end{tabular}

Table 1 (continued)

\begin{tabular}{|c|c|c|c|c|}
\hline \multicolumn{2}{|c|}{ Eruption timing } & \multirow{2}{*}{$\begin{array}{l}\text { Eruption } \\
\text { type }\end{array}$} & \multirow[t]{2}{*}{ Rift zone } & \multirow{2}{*}{$\begin{array}{l}\text { Volume } \\
\left(106 \mathrm{~m}^{3}\right)\end{array}$} \\
\hline $\begin{array}{l}\text { Start } \\
\text { (dd/mm/yy) }\end{array}$ & $\begin{array}{l}\text { End } \\
\text { (dd/mm/yy) }\end{array}$ & & & \\
\hline 9/21/2008 & $10 / 2 / 2008$ & Summit & N25-30 RZ & 1 \\
\hline $11 / 27 / 2008$ & $11 / 28 / 2008$ & Summit & N25-30 RZ & 0.1 \\
\hline $12 / 14 / 2008$ & $2 / 4 / 2009$ & Summit & $\mathrm{N} 25-30 \mathrm{RZ}$ & 1.5 \\
\hline 11/5/2009 & $11 / 6 / 2009$ & Summit & N120 RZ & 0.14 \\
\hline $12 / 14 / 2009$ & $12 / 15 / 2009$ & Summit & N25-30 RZ & 0.16 \\
\hline $1 / 2 / 2010$ & $1 / 12 / 2010$ & Summit & N25-30 RZ & 1.2 \\
\hline $10 / 14 / 2010$ & $10 / 31 / 2010$ & Flank & South-east RZ & 2.7 \\
\hline 12/9/2010 & $12 / 10 / 2010$ & Summit & N25-30 RZ & 0.53 \\
\hline $6 / 20 / 2014$ & $6 / 21 / 2014$ & Summit & N120 RZ & 0.3 \\
\hline
\end{tabular}

the above-mentioned rift zones. They are located on the northern flank of the massif (Piton de l'Etang, Piton Armand, and Piton Belle Rive) and on the west flank belonging to the Ancient Piton de la Fournaise (older than 290 ka; Fig. 2b).

\subsection{Distribution of cone and eruption volumes}

At the edifice scale, cinder cone volumes show a slightly asymmetric gaussian distribution extending over 7 orders of magnitude, between $10^{1}$ and $10^{8} \mathrm{~m}^{3}$, with a mean value of $8.6 \times 10^{5} \mathrm{~m}^{3}$ and a main mode between $10^{4}$ and $10^{5} \mathrm{~m}^{3}$ (ca. $30 \%$ of the total dataset: median of $4.2 \times 10^{4} \mathrm{~m}^{3}$; Table 2; Fig. 7). This skewed distribution is mostly influenced by the abundance of small cones inside the Enclos Fouqué caldera, where about $45 \%$ of the volumes range between $10^{3}$ and $10^{5} \mathrm{~m}^{3}$ (median of $7.2 \times 10^{3} \mathrm{~m}^{3}$ ). A quite distinct distribution with respect to the Enclos Fouqué is observed on the NW-SE rift zone and the South Volcanic Zone, where volumes of the cones are on average two orders of magnitude larger than those inside the Enclos Fouqué caldera. Finally, the cones along the NE and SE rift zones have intermediate volumes between those of the Enclos Fouque and of the NE-SW rift zone. Cone distribution along the SE and NE rift zones is similar, with fewer but slightly larger cones along the NE rift zone (median of $2 \times 10^{5} \mathrm{~m}^{3}$ ) than along the SE rift zone (median of $3.7 \times 10^{4} \mathrm{~m}^{3}$ ) (Table 2 ).

\subsection{Magma extrusion rate}

The correlation between the cone volume and the associated lava flow computed from 241 cone-forming eruptions (Fig. 4) enables an estimate of the total bulk volume of magma (lava + cinder cones) extruded along each rift zone. On the one side, this estimate does not take into account the amount of ash and lapillis deposited outside the cone area. However, we consider that this amount is much lower than that of the lava flows, because of the very low average explosivity of Piton de la Fournaise eruptions (Michon et al., 2013; Morandi et al., in press). As already pointed by Wood (1980), bulk flow volumes are much larger than cone volumes (Table 2). At the edifice scale, the total magma volume related to the cone-forming eruptions attains $7.2 \mathrm{~km}^{3}$, $92 \%$ of this volume corresponding to lava flows (Table 2). Half of this total volume (48\%) has been emitted along the NW-SE rift zone, the rest being distributed between the NE and SE rift zones (17.6\%), the South Volcanic Zone (13\%), and the Enclos Fouqué caldera (11,4\%).

On the basis of the little existing time constrains, these volumes may be used to estimate the magma emission rate of each rift zone. The floor of the Enclos Fouqué caldera is made of a pahoehoe lava field dated at 1730-1790 CE (Lénat et al., 2001a; Michon et al., 2013), making an upper limit of around 250 years for the age of the cones. Moreover, more than $95 \%$ of these cones developed during the last 100 years, after a period of intense summit activity characterised by the succession of several lava lakes (Michon et al., 2013). Thus, an average emission rate of $0.1-0.25 \mathrm{~m}^{3} \mathrm{~s}^{-1}$ can be estimated for the Enclos Fouqué caldera. These values agree with the emission rate of $0.32 \mathrm{~m}^{3} \mathrm{~s}^{-1}$ reported for the period ranging between 1931 and 1981 (Bachèlery, 1981). We 


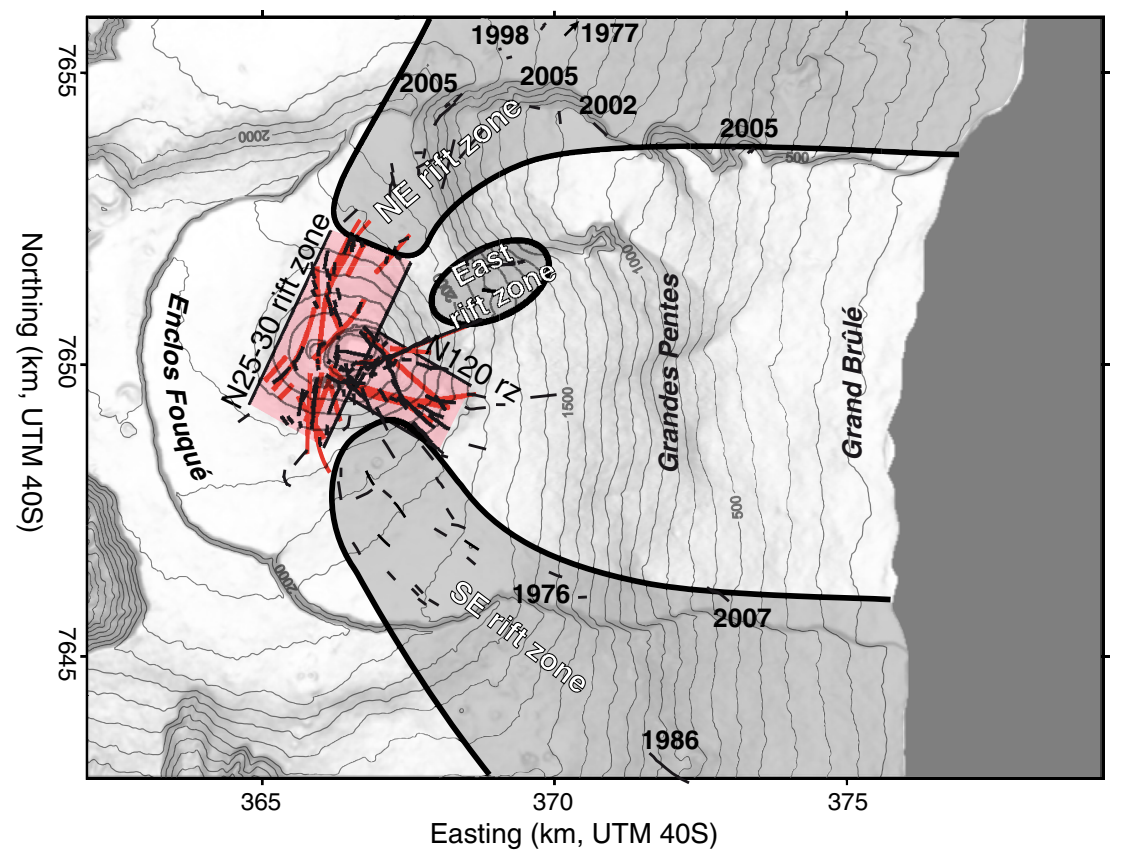

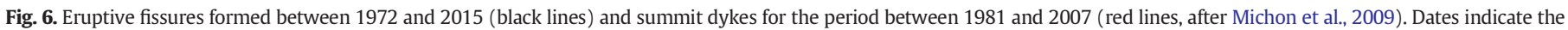

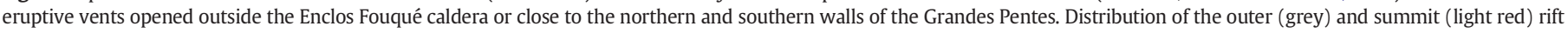
zones related to the flank and summit eruptions, respectively.

stress here that this emission rate does not include the volume of the lavas emitted during long-lasting lava lake activity from the Central Cone (Michon et al., 2013)

The lava flows of the NE and SE flanks of Piton de la Fournaise, on which the identified cones developed, were at least in part emitted from a central activity prior to the collapse of the Enclos Fouqué caldera. Cosmogenic dating suggests a caldera collapse between 4880 and 2855 BP (Bachèlery, 1981; Staudacher and Allègre, 1993; Morandi et al., in press). Thus, assuming that most of the cones identified along the NE and SE rift zones have been built after the Enclos Fouqué caldera collapse, a magma production rates of $4-7.3 \times 10^{-3} \mathrm{~m}^{3} \mathrm{~s}^{-1}$ can be estimated for the SE and NE rift zones, respectively. This is clearly a maximum estimate as part of the cones likely formed before the Enclos Fouqué collapse, but is a realistic estimate because of the frequent and recent activity in this area (Morandi et al., in press). The production rates along these rift zones are consequently at least two orders of magnitude lower than in the Enclos Fouqué caldera (Table 2). Finally, very few data exist to constrain the age of the beginning of the volcanic activity along the NW-SE rift zone and the South Volcanic Zone. The oldest dated cone of the NW-SE rift zone and a basal lava flow in the South Volcanic Zone suggest a volcanic onset in the range of 30-60 ka along these volcanic lineaments (McDougall, 1971). We estimate extrusion rates of $0.5-1.0 \times 10^{-3}$ and $1.8-3.6 \times 10^{-3} \mathrm{~m}^{3} \mathrm{~s}^{-1}$ for the South Volcanic Zone and the NW-SE rift zone, respectively.
To sum up, cinder cones are about two orders of magnitude smaller in the Enclos Fouque caldera than on the volcano flanks and the production rate is two orders larger in the caldera than outside the Enclos Fouqué.

\subsection{Geometry of the seismogenic zones}

Between 1996 and 2014, the OVPF staff manually located 8193 hypocenters related to VT events below the massif of Piton de la Fournaise. This dataset reveals that $96 \%$ of the localised seismicity developed above the Moho, i.e. above $11 \mathrm{~km}$ bsl (Charvis et al., 1999), almost exclusively below the Enclos Fouqué caldera (Fig. 8a). It occurs primarily along a subvertical seismic plug, dipping $80^{\circ}$ towards the west, located immediately below the summit down to about $8 \mathrm{~km}$ bsl (Fig. 9). The lower half of this seismic zone was particularly active during the upward magma migration that preceded the March 1998 eruption (Battaglia et al., 2005a) and to a lesser extent after the April 2007 summit caldera collapse that was followed by a downward migration of the seismic source (Massin et al., 2011). The upper part of the seismic pipe, above sea level, is mostly characterised by an increasing seismicity before each eruption/intrusion recorded since at least 1985 (Roult et al., 2012) and by an intense activity during pit-crater collapses (Hirn et al., 1991; Longpré et al., 2007; Massin et al., 2011). A second seismic zone is defined north-east of this finger-shaped swarm, where the

Table 2

Cone and volume distributions along the rift zones of Piton de la Fournaise. SVZ: South Volcanic Zone.

\begin{tabular}{|c|c|c|c|c|c|c|c|c|}
\hline & \multicolumn{3}{|l|}{ Cones } & \multicolumn{3}{|c|}{$\begin{array}{l}\text { Magma volume } \\
\left(\mathrm{m}^{3}\right)\end{array}$} & \multirow[t]{2}{*}{ Inferred age } & \multirow[t]{2}{*}{$\begin{array}{l}\text { Production rate } \\
\left(\mathrm{m}^{3} \mathrm{~s}^{-1}\right)\end{array}$} \\
\hline & Number & $\begin{array}{l}\text { Median volume } \\
\left(\mathrm{m}^{3}\right)\end{array}$ & $\begin{array}{l}\text { Mean volume } \\
\left(\mathrm{m}^{3}\right)\end{array}$ & Cone & Lava flows & Total & & \\
\hline Enclos Fouqué & 287 & $7.2 \times 10^{3}$ & $3.7 \times 10^{4}$ & $1.1 \times 10^{7}$ & $8.2 \times 10^{8}$ & $8.3 \times 10^{8}$ & $250-100 \mathrm{yr}$ & $0.10-0.26$ \\
\hline SE rift zone & 101 & $3.7 \times 10^{4}$ & $2.1 \times 10^{5}$ & $2.1 \times 10^{7}$ & $6.3 \times 10^{8}$ & $6.5 \times 10^{8}$ & $4880-2855 \mathrm{yr}$ & $4.2-7.3 \times 10^{-3}$ \\
\hline NE rift zone & 48 & $2.0 \times 10^{5}$ & $5.9 \times 10^{5}$ & $2.8 \times 10^{7}$ & $5.9 \times 10^{8}$ & $6.2 \times 10^{8}$ & $4880-2855 \mathrm{yr}$ & $4.0-6.9 \times 10^{-3}$ \\
\hline NW-SE rift zone & 161 & $5.3 \times 10^{5}$ & $2.0 \times 10^{6}$ & $3.2 \times 10^{8}$ & $3.1 \times 10^{9}$ & $3.45 \times 10^{9}$ & $60-30 \mathrm{ka}$ & $1.8-3.6 \times 10^{-3}$ \\
\hline SVZ & 28 & $2.3 \times 10^{6}$ & $3.7 \times 10^{6}$ & $1.0 \times 10^{8}$ & $8.4 \times 10^{8}$ & $9.4 \times 10^{8}$ & 60-30 ka & $0.5-1.0 \times 10^{-3}$ \\
\hline Total & 644 & $4.2 \times 10^{4}$ & $8.6 \times 10^{5}$ & $5.6 \times 10^{8}$ & $6.6 \times 10^{9}$ & $7.2 \times 10^{9}$ & & \\
\hline
\end{tabular}



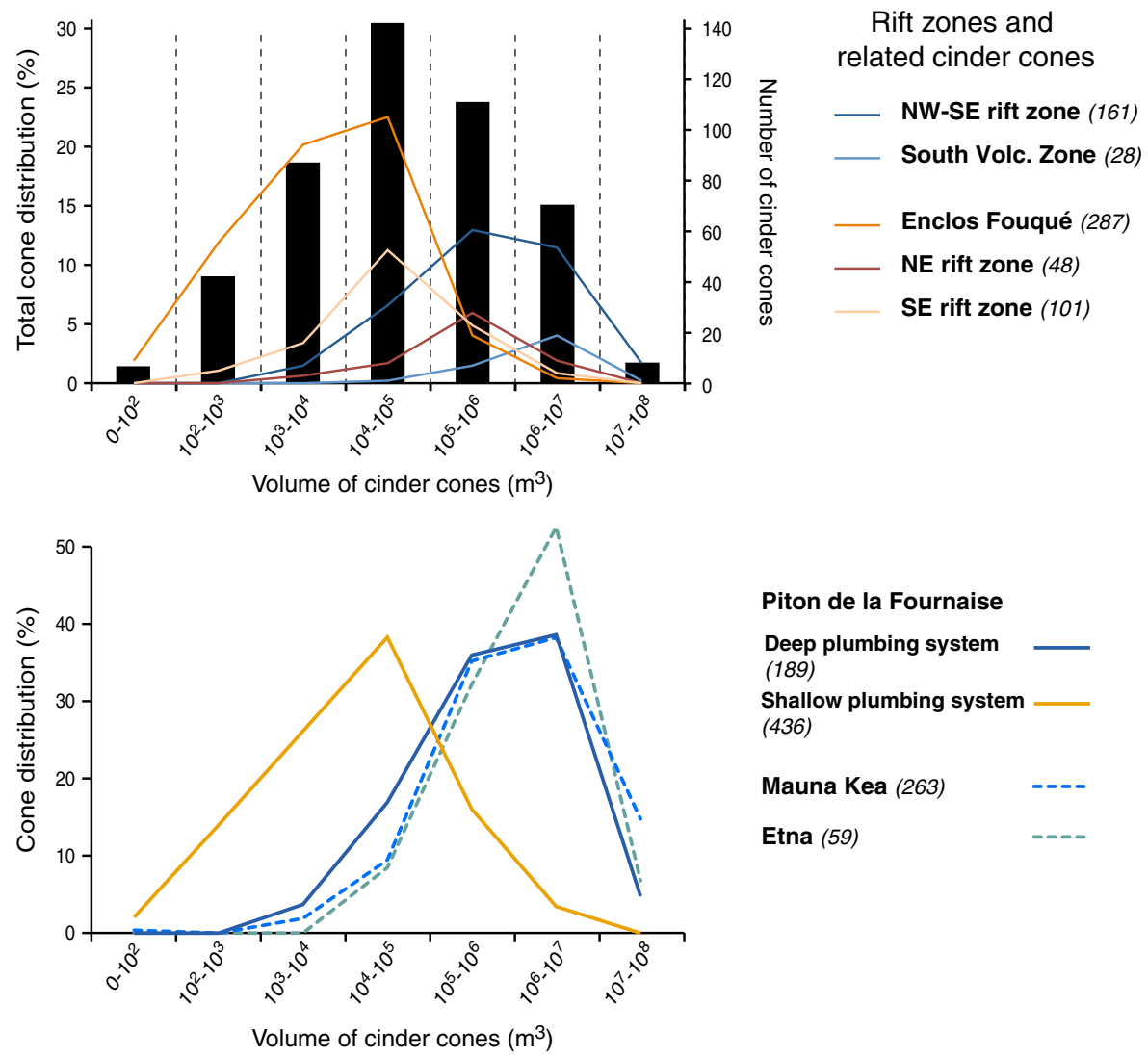

Piton de la Fournaise

Deep plumbing system (189)

Shallow plumbing system

(436)

Mauna Kea (263)

Etna (59)

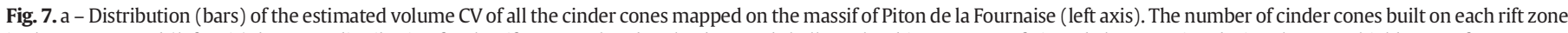

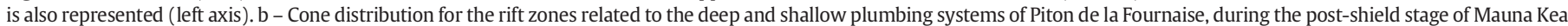
(data from Kervyn et al., 2012) and at Mount Etna (data from Wadge, 1977; Neri et al., 2011).

seismicity is concentrated in an east dipping zone rooted at about $4 \mathrm{~km}$ bsl (Fig. 9). Albeit less frequent than along the subvertical plug, this seismicity is temporally correlated to the phases of volcano unrest (Massin et al., 2011).

At depth greater than $11 \mathrm{~km}$ bsl, that is, below the oceanic crust (Charvis et al., 1999), the VT events appear much more scattered (Figs. 8b-c, 9). Interestingly, the distribution of the hypocenters differs above and below $20 \mathrm{~km}$ bsl. Between the Moho and $20 \mathrm{~km}$ bsl, most of the events occur between the summits of Piton des Neiges and Piton de la Fournaise along a N120 trending axis, which is remarkably parallel to the NW-SE rift zone defined from the cinder cone distribution (Fig. 8b). At depth between 20 and $40 \mathrm{~km}$ bsl, VT events are mostly distributed along a N30-40 trending zone, orthogonal to the N120 axis, and along a smaller zone, oriented N90, parallel to the northern scarp of the Grandes Pentes and Grand Brûlé (Fig. 8c). It is noteworthy that the southern part of the N30-40 zone was seismically active after the 2007 eruption and caldera collapse, when VT events progressively migrated downward from the summit down to $28-33 \mathrm{~km}$ below the west flank (Massin, 2009). The northern part was active in 2014 and preceded the restart of the volcanic activity after 3.5 years of quiescence and deflation. Downward migration of the seismicity, comparable to that recorded in 2007, was recorded during the Eyjafjallajökul 2010 eruption, where it was interpreted as the result of downwardpropagating decompression of the plumbing system (Tarasewicz et al., 2012). In the case of Piton de la Fournaise, whatever the cause of the earthquake migration, it suggests a link between the summit activity and the eccentric seismic activity at depths as large as $33 \mathrm{~km}$.

Finally, among the different rift zones determined from the cinder cone and eruptive fissure distributions, only the NW-SE rift zone and the rift zone segments inside the Enclos Fouqué caldera are associated with frequent seismicity (Figs. 8, 9), while the NE and SE rift zones, the South Volcanic Zone, and the Puys Ramond volcanic alignment are largely aseismic.

\section{Discussion}

The present study allows the identification of several rift zones cutting the massif of Piton de la Fournaise shield volcano: the NW-SE rift zone, the South Volcanic Zone, the NE and SE outer rift zones, the N25-30 and N120 summit rift zones inside the Enclos Fouqué caldera, and the Puys Raymond volcanic alignment. All these rift zones differ essentially in terms of geometry, size, seismic activity, size of the volcanic cones, magma transfer, and magma output rate. Our work also provides the first complete picture of the seismicity distribution over the whole island, with shallow VT events mostly restricted below the Enclos Fouqué caldera and deep VT events concentrated along two orthogonal N30-40 and N120 axes.

\subsection{Geometry of the plumbing system}

We showed above that VT events are distributed between the surface down to around $35 \mathrm{~km}$ bsl and concentrated in seismic zones located east and west of the summit below the oceanic crust (Figs. 8 and 9). If the shallow seismicity ( $>8 \mathrm{~km} \mathrm{bsl}$ ) is closely (spatially and temporally) associated with the volcanic activity within the Enclos Fouqué caldera (e.g. Battaglia et al., 2005a; Massin et al., 2011), eccentric deep seismic activity can precede of years (e.g. 1996-1998) or follow of several months (e.g. April-August 2007) the central volcanic activity. It is thus crucial to assess the origin of the deep VT events located in the mantle lithosphere. At Kilauea, several mechanisms have been proposed to explain the occurrence of deep VT earthquakes below its southern flank (Wright and Klein, 2006). Earthquakes could stem from (1) lithospheric 

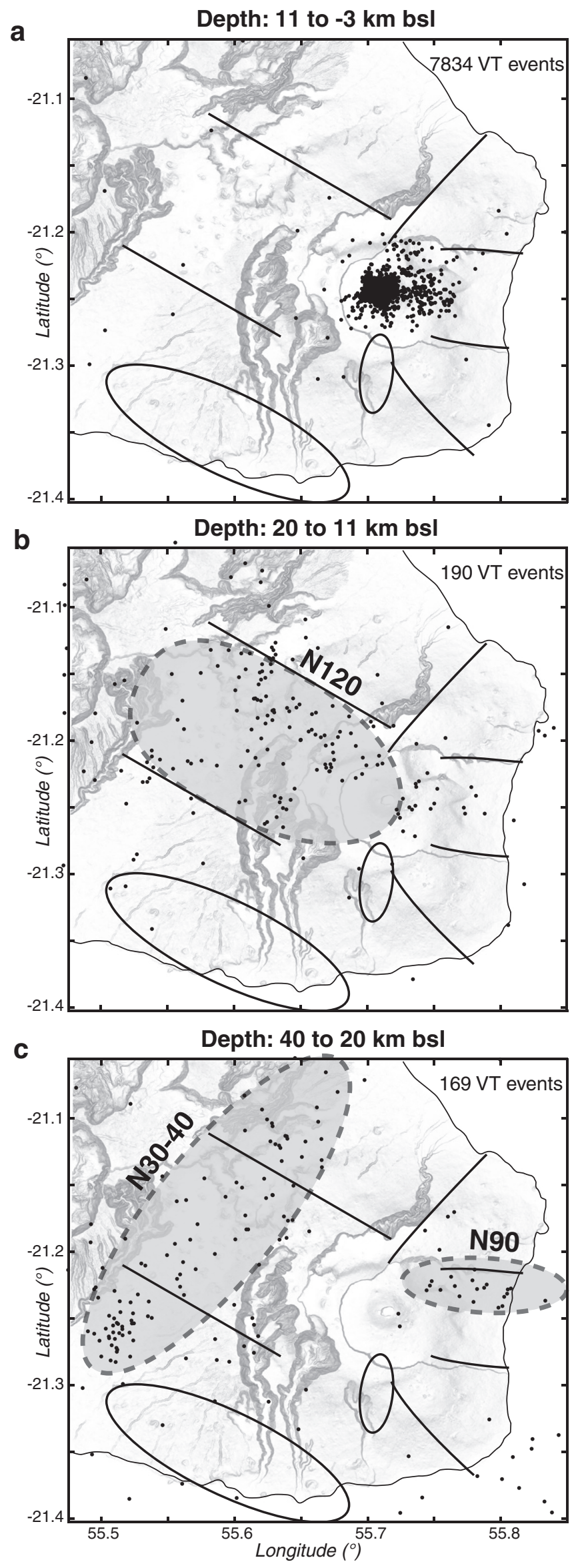

adjustments associated with plate movements, (2) lithospheric adjustments related to the load of the edifice, (3) stresses imposed by the southward flank spreading, and/or (4) stresses related to the magma conduit caused by overpressure or conduit-related disturbances of regional stresses. In the case of Piton de la Fournaise, factors 1 and 3 probably have a very little influence since the African plate moves much more slowly than the Pacific plate $(\sim 2 \mathrm{~cm} / \mathrm{yr}$ for La Réunion and 7$10 \mathrm{~cm} / \mathrm{yr}$ in Hawaii relative to the hotspot referential; Müller et al., 1993; Gripp and Gordon, 2002; Bachèlery and Villeneuve, 2013) and only old events of major flank spreading have been identified and confined to the Piton des Neiges edifice (Le Friant et al., 2011). Contrary to Hawaii, the lithosphere below La Réunion does not show any downward flexure (de Voogd et al., 1999). However, the opposite forces imposed on the lithosphere (i.e. upward forces originating from the plume-related lithosphere thermal thinning and downward forces due to the load of the edifice) are potentially able to produce shear stresses and consequently earthquakes within the lithosphere below the whole La Réunion edifice (Michon et al., 2007). Finally, the temporal and spatial association of the deep N30-40 and N120 seismic zones and the eruptive activity of Piton de la Fournaise described above suggest, like for Kilauea (Wright and Klein, 2006), Etna (Patanè et al., 2013), and El Hierro (López et al., 2012), that VT events within the identified seismic zones are possibly related to stresses of magmatic origin. These VT may represent the seismically detectable response of the lithosphere and of the volcanic edifice to the upward movement of magma and related fluids. The important $\mathrm{CO}_{2}$ magma degassing recorded close to the centre of Piton des Neiges (Marty et al., 1993) and right above the deep N3040 and N120 seismic zones supports the occurrence of deep fluid streaming from deep magmatic sources and percolating through the volcanic edifices (Liuzzo et al., 2014). In such a general frame, open questions still remain about the origin of the small N90 seismic zone east of the central zone. Available data do not permit to assess whether this zone is disconnected from any fluid transfer or it corresponds to a local eccentric magma transfer zone like the ones identified along the rift zones of Kilauea (Klein et al., 1987).

We showed that the deep seismic zones are organised in two orthogonal directions, i.e. N30-40 and N120, and along a third, smaller N90 orientation (Fig. 8 b-c). At a regional scale, the two perpendicular directions have long been recognised as two main structural orientations represented by Cretaceous transform faults and paleo-spreading axes in the Mascarene basin (Schlich and Fondeur, 1974; Dyment, 1991). The N90 direction also coincides to that of the magnetic anomalies of the oceanic lithosphere locally found east of La Réunion, between the island and the Mauritius transform zone (Lénat et al., 2001b). Such a parallelism strongly suggests that the deep magma transfer is controlled by inherited or reactivated structures within the lithosphere. Plotting the hypocentres along these two axes instead of the classical EW-NS directions reveals the most likely paths of magma transfer, which can be divided in two laterally shifted subsystems: a deep plumbing system below the oceanic crust located straight below the La Réunion edifice, west of Piton de la Fournaise, and a shallow one above the Moho $(<11 \mathrm{~km}$ bsl) located below the Central Cone (Fig. 10). The deep path is vertical from $35 \mathrm{~km}$ depth to $15-20 \mathrm{~km}$ bsl and has a N30-40 orientation. This depth range remarkably matches the pressure range (about $1 \mathrm{GPa}$ ) determined for the deep fractional crystallisation of primitive basalts emitted by Cône Catherine, a submarine cone built $10 \mathrm{~km}$ from the coast in the northward continuity of the N30-40 deep seismic zone (Fretzdorff and Hasse, 2002). High pressures of magma crystallisation (up to 4-5 kbar) are also recorded in melt and fluid inclusions hosted in olivine-rich basalts (Piton de Caille oceanite) and dunite xenoliths (Piton Chisny) erupted along the NW-SE rift zone (Fig. 10; Bureau

Fig. 8. Spatial distribution of the volcano-tectonic (VT) events located above the Moho (a), in the mantle lithosphere between 11 and $20 \mathrm{~km} \mathrm{bsl} \mathrm{(b),} \mathrm{and} \mathrm{between} 20$ and $40 \mathrm{~km}$ bsl (c). The location of the rift zones determined from the cinder cone density map is indicated for comparison. 


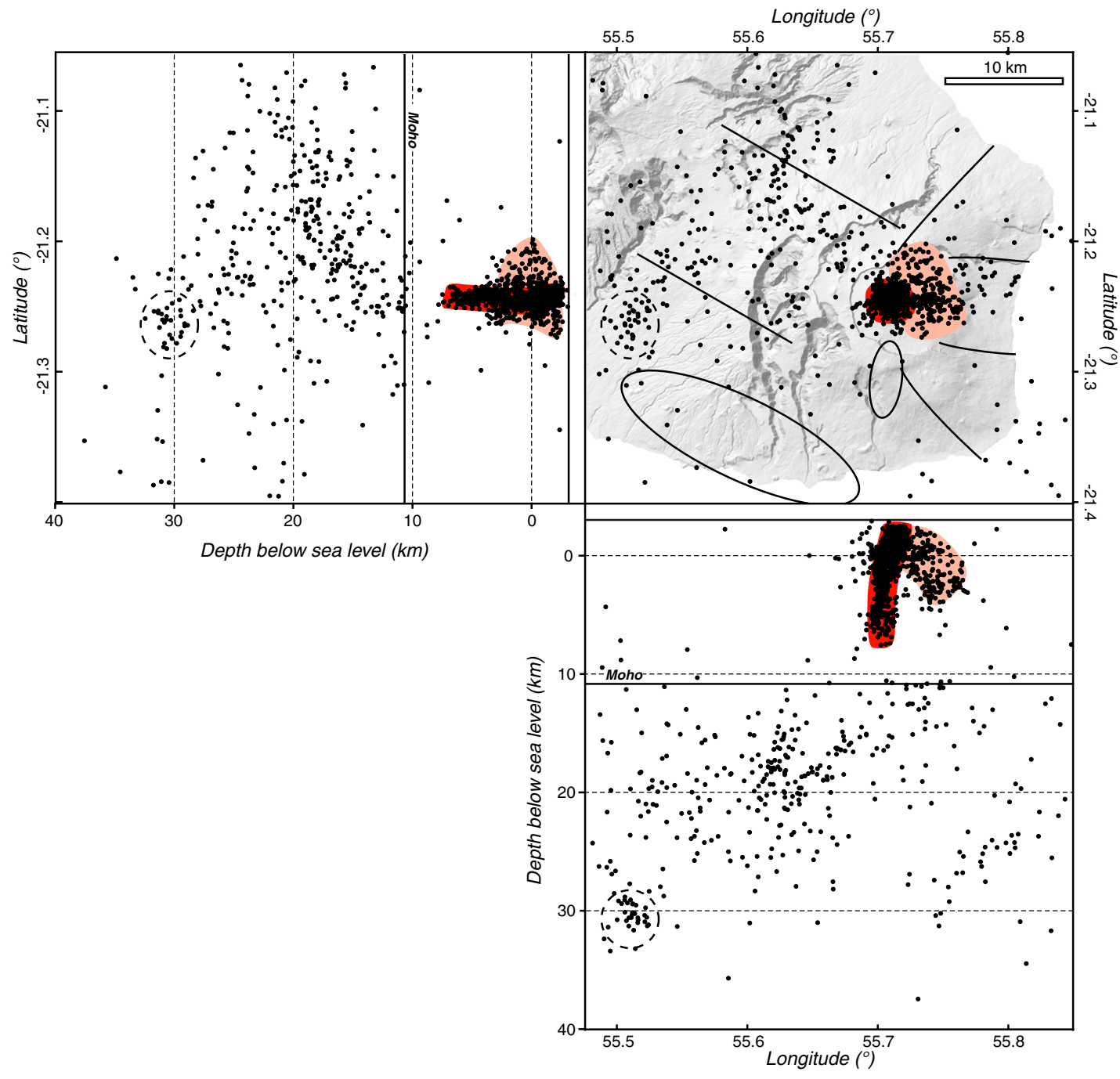

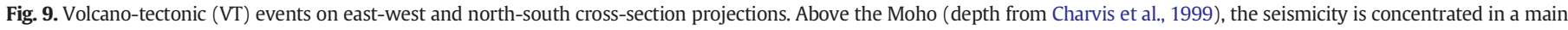

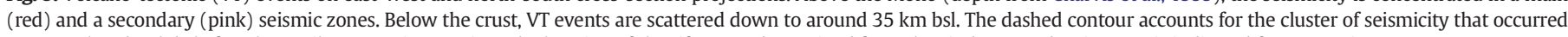
at 28-33 km depth bsl after the April 2007 main eruption. The location of the rift zones determined from the cinder cone density map is indicated for comparison.

et al., 1999). At 15-20 km depth, the distribution of the VT events suggests a N120 prominently horizontal transport path, in which magma is channelised and concentrated below the Moho at the vertical of volcano's summit. Although the structural control of the lithosphere on the orientation of seismically active alignments (N30-40 and N120) is relatively evident, the origin of the switch from vertical to horizontal is much less understood. For instance, the load effect of a volcanic edifice (Muller et al., 2001; Watanabe et al., 2002), the occurrence of a deep region of neutral buoyancy within which lateral transport is favoured (Ryan, 1988), or a major lithological discontinuity could equally explain the SE deflection of the plumbing system. Further work is required to address this issue.

Seismically speaking, the deep and shallow plumbing systems are vertically disconnected by an aseismic level located in the lower oceanic crust between 8 and $11 \mathrm{~km}$ bsl (Fig. 10). At this depth, the oceanic lithosphere is theoretically characterised by a brittle behaviour (Ranalli and Murphy, 1987), except if it has been thermally rejuvenated by volcanic activity (Menard and McNutt, 1982). Pressures recorded in olivine hosted melt and fluid inclusions from central magmas are typically lower than 1 kbar (Bureau et al., 1998a; Famin et al., 2009; Di Muro et al., 2014). Thus, instead of interpreting the lack of seismicity between 8 and $11 \mathrm{~km}$ as a result of a local disappearance of shear stresses in an overall brittle crust, we tentatively propose that this zone is mechanically governed by a ductile rheology, which could arise from (1) the upward migration of the isotherms above the mantle thermal anomaly and/or (2) the occurrence of a deep zone of magma storage. Interestingly, this depth range is only recorded in some $\mathrm{CO}_{2}$-rich melt inclusion trapped in magnesian olivines of 1998 Hudson eruption (2-7 kbar; Bureau et al., 1999) whose eruption was preceded by eccentric seismicity on the NW-SE rift zone.

Above $8 \mathrm{~km}$ bsl, the shallow plumbing system displays an overall vertical geometry restricted to the Enclos Fouqué caldera. This shallow system, which is intermittently recharged by deep magmas (Di Muro et al., 2014; Fontaine et al., 2014), feeds short-lived eruptions in the Enclos Fouqué caldera that are preceded by an increase in the shallow seismicity and summit inflation (Peltier et al., 2009; Roult et al., 2012). Geophysical and geochemical data suggest that the shallow magma path is characterised by several levels of magma storage mostly organised in small pockets/sills rather than in a single large and chemically zoned magma reservoir (Albarède et al., 1997; Prôno et al., 2009; Massin et al., 2011; Di Muro et al., 2014). In this overall frame, geochemical difference between central and lateral (NW-SE) volcanic zones can arise from distinct depth of fractionation of the magmas, deep storage, and clinopyroxene crystallisation being possibly favoured below the poorly active NW-SE rift zone (Albarède et al., 1997).

To sum up, our seismological data allow for the first time to propose a link between different portions of the magma plumbing system 
a

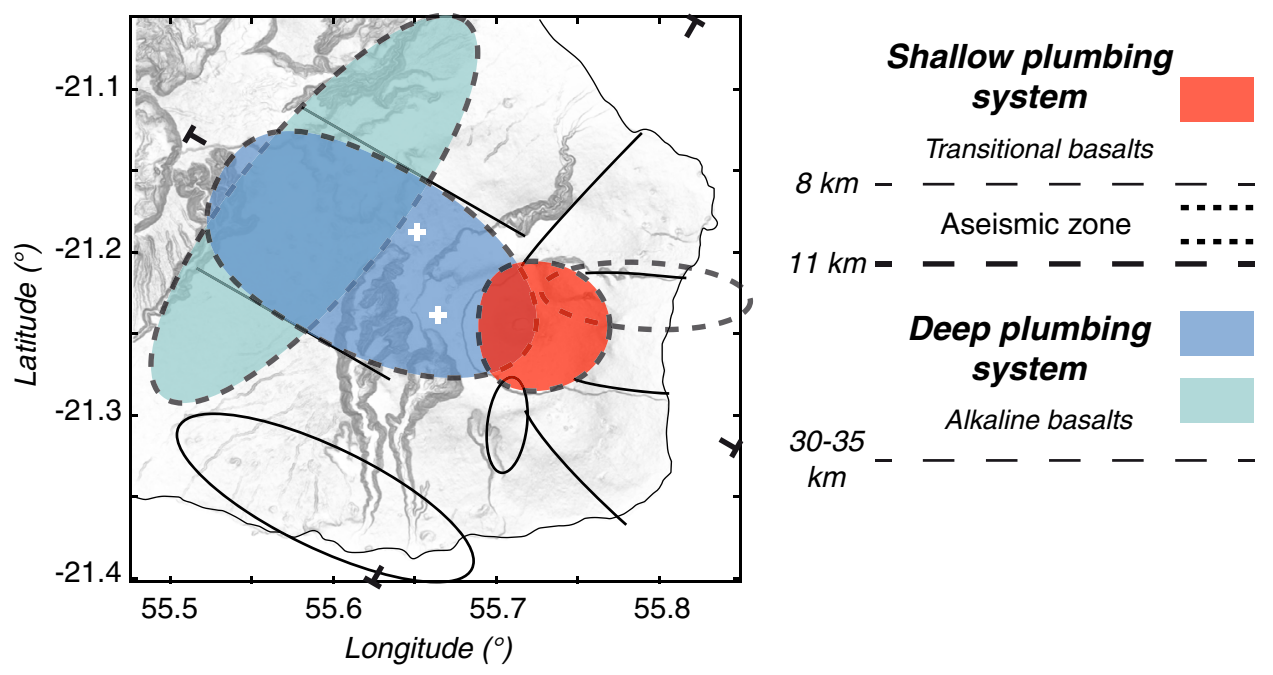

b

NW

Piton de la
Fournaise

C

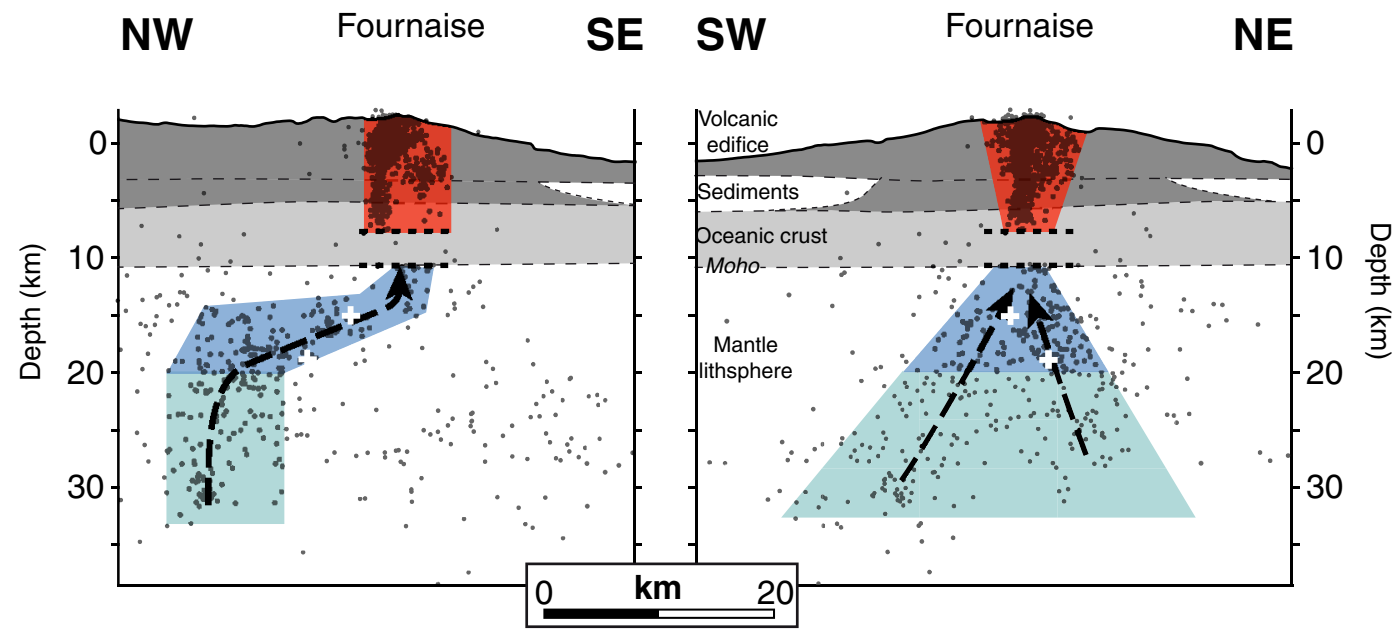

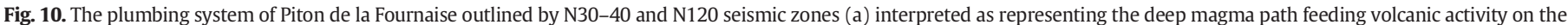

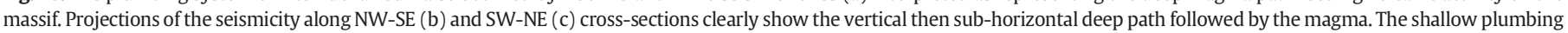

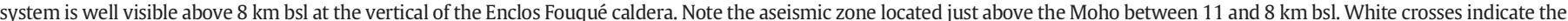

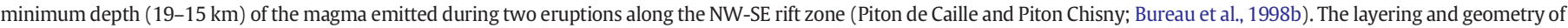
the crust and of the edifice are modified from Gallart et al. (1999). See text for explanations.

feeding the volcanic activity, from 30 to $35 \mathrm{~km}$ bsl to the summit of Piton de la Fournaise. This system is not developed only at the vertical of the volcano but presents a lateral offset of about $15 \mathrm{~km}$. An offset of the same range exists in the deep plumbing systems of Etna (Patanè et al., 2013) and Kilauea (Wright and Klein, 2006) indicating that lateral magma migration and storage is not limited to the shallow rift zones (e.g. NE and SE) but also occurs in the deepest parts of the transport path. The process governing this shift remains to be explained. Moreover, the parallel orientations of the regional lithospheric structures and the seismically defined deep plumbing system suggest that stress fields stemming from the reactivation of these structures actively control the magma transport. Finally, the seismic gap separating the deep and shallow plumbing systems at ca. $8 \mathrm{~km}$ (2 kbar) may represent an important level of magma accumulation in a ductile lower crust.

\subsection{Types of rift zone}

Geometry and activity of rift zones are highly sensitive to the interplay between the magma flux, potential flank displacements, and the plumbing system dynamics (e.g. Walker, 1999). The present work reveals that two groups can be identified among the rift zones cutting the massif of Piton de la Fournaise. One the one hand, the dynamics of the eruptions inside the Enclos Fouque caldera and the associated shallow seismicity suggest that the summit (N25-30 and N120) and outer (NE, E, and SE) rift zones are related to the activity of the shallow plumbing system (<11 km below volcano summit). The overall eruption frequency is of 1.1 event/year since 1900 but the lower portions of the SE and NE rift zones, i.e outside the Enclos Fouqué caldera, are much less active. During the last century, the average magma emission rate remained relatively constant at $0.32 \mathrm{~m}^{3} \cdot \mathrm{s}^{-1}$ (Bachèlery, 1981; Staudacher et al., in press), a value consistent with our long-term estimate based on a larger database of eruptions (Table 2). On the other hand, the location of the NW-SE rift zone at the vertical of the N120 trending portion of the deep plumbing system (Fig. 10) and the deep magma crystallisation recorded in magmas erupted along this rift zone suggest that the NW-SE rift zone plays a major role in the lateral and vertical deep magma transfer. The available radiocarbon ages indicate an eruption frequency of 1 eruption every 200 years (Morandi et al., in press), the magma flux is of $1.8-3.6 \times 10^{-3} \mathrm{~m}^{3} . \mathrm{s}^{-1}$, i.e. two orders of magnitude lower than that of the central zone, and the average volume 
of the cinder cone along the NW-SE rift zone is larger than along the other sectors (Table 2). Finally, the magma chemical composition differs from that related to the summit path by a higher alkalinity and lower $\mathrm{Ca} / \mathrm{Al}_{2} \mathrm{O}_{3}$ content (Bureau, 1998a, 1998b; Famin et al., 2009; Lénat et al., 2012).

A striking feature arising from our analysis is the similarities shared by the rift zones related to the summit and deep plumbing systems of Piton de la Fournaise and those developed on volcanoes of Hawaii during the shield and post-shield stages, respectively. In Hawaii, when volcanoes move from shield-building to post-shield stages as they drift away from the hotspot, (1) the magma composition evolves from tholeiitic to alkaline suites with higher $\mathrm{Mg}$ and lower $\mathrm{CaO} / \mathrm{Al}_{2} \mathrm{O}_{3}$ contents, (2) the eruption frequency and (3) the magma flux drop of two orders of magnitude, (4) the shallow magma reservoir disappears and only remains the deep magma-storage zones, at depth in excess of $15 \mathrm{~km}$ (Clague, 1987; Wolfe et al., 1997; Clague and Sherrod, 2014), (5) the rift zones widen, and (6) the vent morphology generally evolves from low edifices to large cinder cones (Walker, 1999). These 6 specificities are also found on the rift zones of Piton de la Fournaise where, for instance, the volumes of the cinder cones related to the deep plumbing system remarkably match those of the post-shield stage of Mauna Kea (Fig. 7b).

Thus, according to the classification of Hawaiian volcanoes, the NW-SE rift zone is typical of the post-shield stage while the summit and outer rift zones related to the shallow plumbing system represents a shield-building stage. However, a temporal evolution does not stand for rift zones of Piton de la Fournaise as their activity is coeval for at least $29 \mathrm{ka}$. In consequence, we show that rift zones akin to those of the shield-building and post-shield stages (1) can have a contemporaneous activity on basaltic volcanoes like Piton de la Fournaise and (2) are fed by two different portions of a single plumbing system.

The interpretations proposed for Hawaiian volcanoes to explain the shift from shield to post-shield magmatism invoke a decrease in the amount of partial melting of the oceanic lithosphere (Chen and Frey, 1983, 1985; Chen et al., 1991), a progressive decrease in partial melting (Feigenson et al., 1983), or a significant deepening of the active magma reservoir (Shamberger and Hammer, 2006). For Piton de la Fournaise, the coeval activity of the "post-shield" and "shield" type rift zones and their link with a single transport path make unlikely a major influence of the degree of partial melting in the synchronous development of the two magma types. This is consistent with the very small chemical and isotopic heterogeneities of the erupted magmas (Albarède et al., 1997; Bosch et al., 2008; Pietruszka et al., 2009; Di Muro et al., 2014). On the contrary, they support a key role of the depth of fractionation with magmas of alkaline affinity (Albarède et al., 1997; Famin et al., 2009) resulting from wherlitic fractionation in the deep plumbing system and transitional basalt originating from a gabbroic fractionation in the shallow plumbing system (Fig. 10; Albarède et al., 1997; Boivin and Bachèlery, 2009). The volume difference of the cinder cones related to the shallow and deep plumbing systems could arise from the combined effect of fewer but on average longer-lasting eruptions with larger volatile contents along the NW-SE rift zone and the South Volcanic Zone than in the other areas.

\subsection{Origin and dynamics of the rift zones}

It has long been proposed that rift zone initiation in oceanic intraplate setting is structurally controlled by lithospheric faults or weak zones (e.g. MacDonald, 1972), reactivated by either the sole hotspot-related crustal doming (Carracedo, 1994; Michon et al., 2007) or by the combined effect of the volcanic-load subsidence and the hotspot-related uplift (Lipman and Calvert, 2011). Once the rift zone developed, the required conditions to maintain continuous extension and to allow recurrent vertical dyke injections may result from i) the ridge-like topography of the rift zone (Fiske and Jackson, 1972), ii) continuous flank destabilisation (Dieterich, 1988; Delaney et al.,
1998; Walter et al., 2005a), and/or iii) regional extension (Walker, 1993).

\subsubsection{NW-SE rift zone and South Volcanic Zone related to the deep plumbing system}

The NW-SE rift zone cutting Piton de la Fournaise volcano and the deep plumbing system feeding its activity are parallel to the main lithospheric structures underlying La Réunion Island. Concerning the South Volcanic Zone for which very few data are available, we tentatively propose that its $\mathrm{N} 120$ elongation is also the consequence of a deep structural control.

If N120 lithospheric faults may initially channelise the upward magma migration to develop the NW-SE rift zone and the South Volcanic Zone, questions remain on the conditions that permit to maintain extension in the edifice and consequently allow recurrent dyke injections along these preferential intrusion paths. Among the different processes to conserve a long-lasting favourable stress field (i.e. subvertical maximum principal stress $\sigma_{1}$ ), the effect of the topographic ridge between Piton des Neiges and Piton de la Fournaise, as considered by Fiske and Jackson (1972) for Hawaiian rift zones, cannot be firmly ruled out for the NW-SE rift zone. However, this interpretation cannot stand for the South Volcanic Zone, which develops on the flank of Piton de la Fournaise. Another potential process to explain the development of the NW-SE rift zone and the South Volcanic Zone could be the continuous destabilisation of the southern and northeastern flanks of La Réunion. Such a deformation usually produces basal compressive structures (e.g. Morgan et al., 2003), can be laterally bounded by strike-slip faults (Acocella et al., 2003; Neri et al., 2004; Siniscalchi et al., 2012), and/or is accompanied by a sliding-related seismicity (Got and Okubo, 2003; Neri et al., 2005). At Piton de la Fournaise, none of these manifestations is recognised, particularly the compressive structures in the submarine flanks and seismicity below the northeastern and/or southern flanks (Fig. 10c), we consider the link between flank destabilisation and the development of both the NW-SE rift zone and the South Volcanic Zone as strongly unlikely. The last known process that can be invoked to maintain a favourable stress field for dyking is the occurrence of a regional extension like in Iceland (Walker, 1993) or at Fuerteventura (Fernández et al., 2006).

Chaput et al. (2014a) recently showed from a thorough structural analysis carried out in Piton des Neiges that this volcano underwent a dominant NNE-SSW extension throughout its period of activity (i.e., between at least 2.2 and $0.03 \mathrm{Ma}$ ). The extension led to the development of a main N120-140 rift zone (Chevallier and Vatin-Perignon, 1982; Chaput et al., 2014a), parallel to the NW-SE rift zone and the South Volcanic Zone. Moreover, our data reveal that the VT seismicity is not restricted to the massif of Piton de la Fournaise but also develops at the scale of La Réunion edifice (Fig. 11a). We saw in Section 5.1 that such a widespread seismicity in the lithosphere may result from a regional extensional stress field caused by opposite stresses (edifice load vs. thermal erosion of the lithosphere), which probably maintain the lithosphere close to failure. Our seismic data also show the existence of a N120 trending, 15-20-km-long seismic zone below the northern flank of the inactive Piton des Neiges (Fig. 11b). Despite a potential error of a few kilometres in the hypocentre location in this area (mainly on the vertical $z$ axis), the seismic zone indisputably affects the oceanic crust and, possibly, the upper part of the mantle lithosphere. The development of this N120 seismic zone away from the active magmatic system may result from an active deformation of the oceanic crust.

In consequence, we propose that the long-lasting activity of the NW-SE rift zone and possibly the South Volcanic Zone is primarily caused by a persistent weak extensional stress field with a horizontal NNE-SSW-directed minimum principal stress $\sigma_{3}$, which allows intermittent magma ascents directly from the deep plumbing system. In this general setting, the concentric distribution of cinder cones built in the Plaine des Sables (see Fig. 1 for location) suggests that volcanotectonic structures like the Enclos Fouqué caldera does not influence 

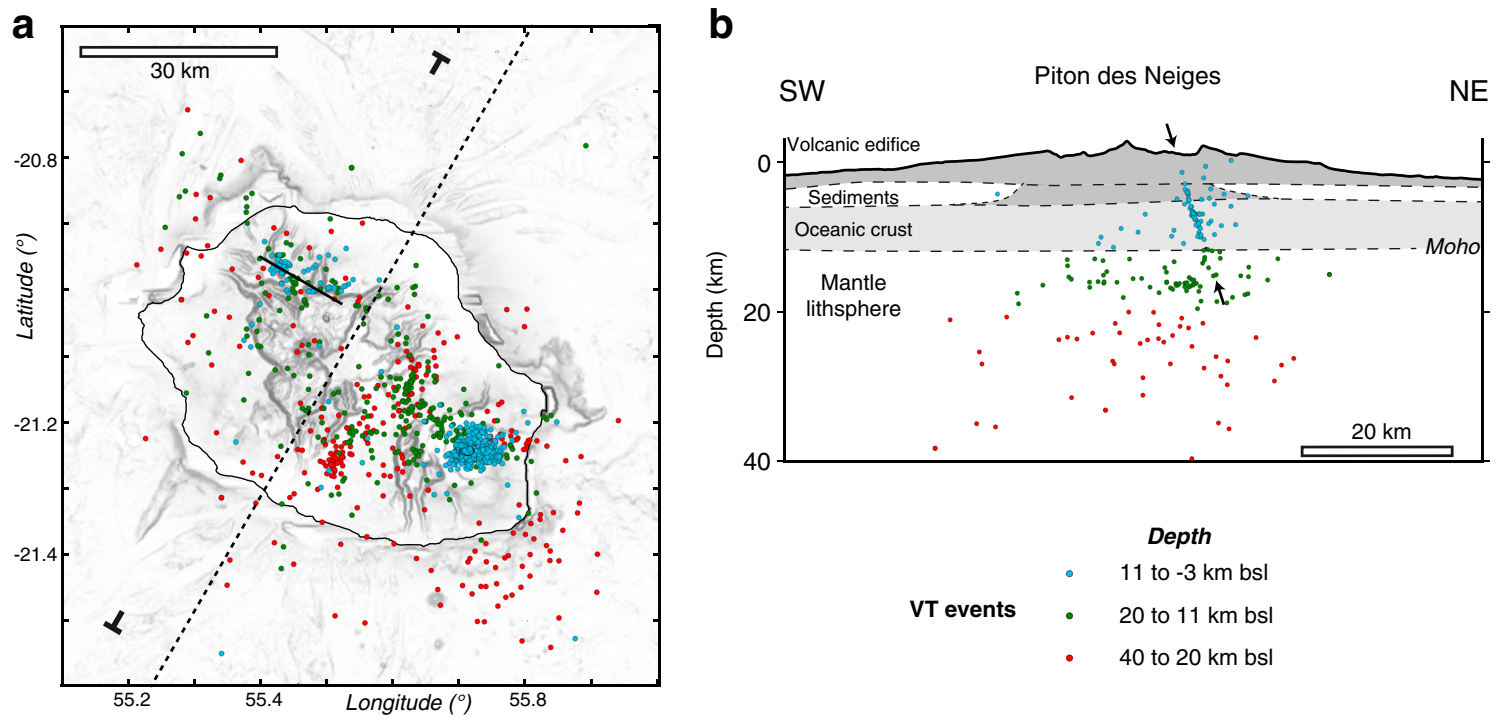

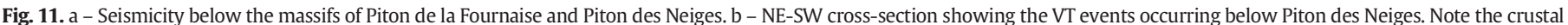
NE-dipping narrow N120 seismic zone highlighted by arrows. See text for explanation.

the overall rift zone geometry but may locally control the magma ascent to the surface.

\subsubsection{Summit and outer rift zones related to the shallow plumbing system}

At Piton de la Fournaise, summit and flank eruptions are associated with distinct systems of rift zones, the summit, and outer rift zones, respectively (Fig. 6). The summit rift zones are restricted to the Central Cone whereas the outer rift zones diverge from the Enclos Fouqué caldera towards the NE and SE flanks. Eruptions along the summit and outer rift zones of Piton de la Fournaise share striking similarities with Etnean eruptions as defined by Acocella and Neri (2003) and Neri et al. (2011). On the one hand, summit eruptions of Piton de la Fournaise and summit and flank (central-lateral) eruptions of Etna volcano both result from a magma vertical ascent below the summit craters, from the shallow plumbing system. Magma then occasionally propagates laterally along shallow dykes $(<1.5-3 \mathrm{~km}$ depth $)$ to feed eruptive fissures. On the other hand, magma involved in eruptions along the outer rift zones of Piton de la Fournaise and flank (eccentric or peripheral) eruptions of Etna follow a distinct path, located east of the summit crater for Piton de la Fournaise and along peripheral dykes at Etna (Acocella and Neri, 2003). Although data are lacking to precisely constrain the geometry of the magma paths related to the summit and flank eruptions of Piton de la Fournaise, we speculate they correspond to the subvertical seismic plug located below the Dolomieu crater and the east dipping seismic zone situated east of Dolomieu, respectively (Fig. 9).

Michon et al. (2009) proposed a structural control for the development of the N25-30 rift zone and a stress permutation model caused

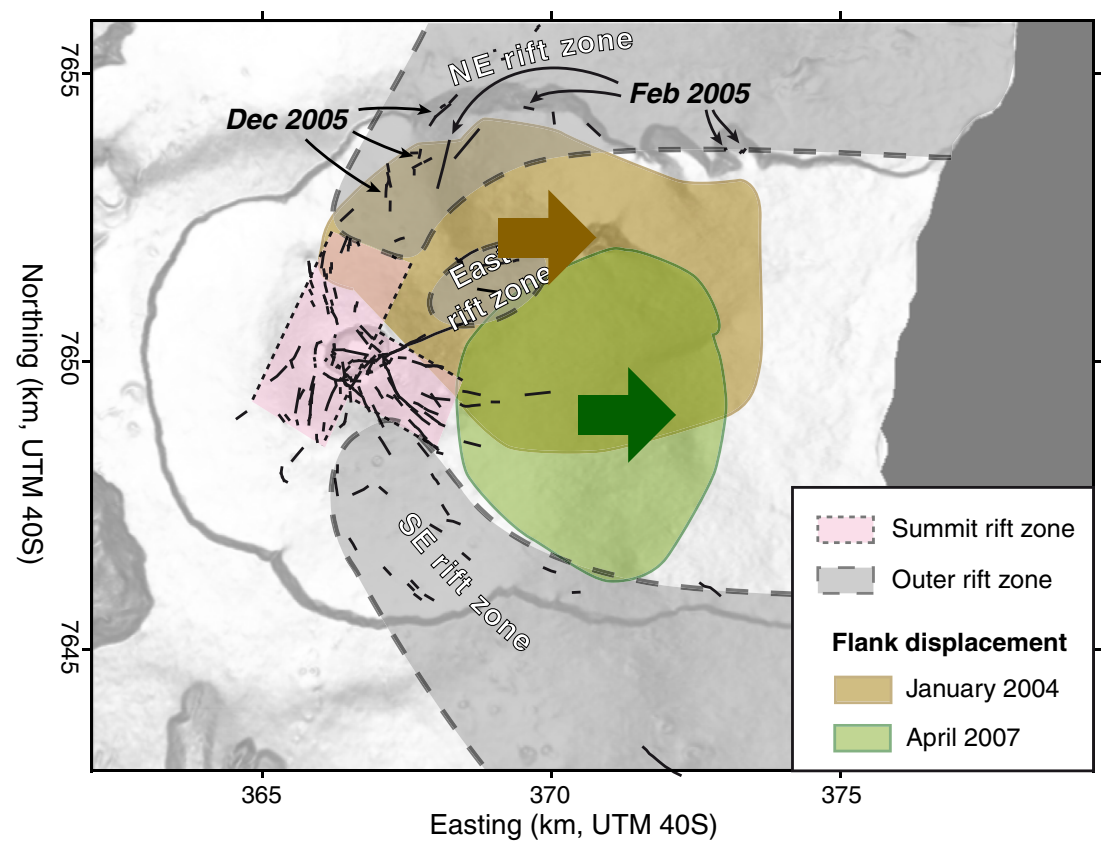

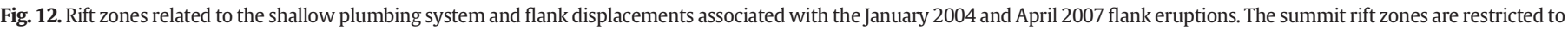

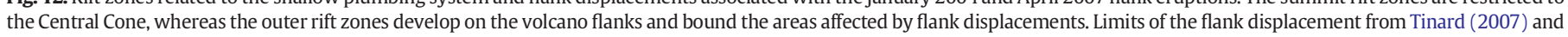
Froger et al. (2015). 
by recurrent subvertical intrusions along this rift zone to explain the subsequent dyke injections in the N120 orthogonal direction. If the subvertical intrusion geometry best explains the deformation recorded during summit eruptions (Froger et al., 2004; Fukushima et al., 2005; Peltier et al., 2008), it cannot account for at least part of the displacements monitored during some flank eruptions, especially the largest displacements (up to $1.4 \mathrm{~m}$ ) that affected the east flank during the January 2004 and April 2007 eruptions (Fig. 12). Such displacements are interpreted as resulting from outward dipping sill injections below the eastern flank of the edifice (Tinard, 2007; Famin and Michon, 2010; Clarke et al., 2013; Di Muro et al., 2014; Froger et al., 2015). According to Chaput et al. (2014a), in the lack of décollement level within the edifice or at the crust/edifice interface, the favourable stress conditions to permit sill intrusions (i.e. subvertical $\sigma_{3}$ ) would be attained by horizontal stress accumulation under the effect of recurrent dyke injections along the rift zones, and the subsequent permutations of the principal stress tensors, as evidenced for Piton des Neiges volcano, the inactive twin of Piton de la Fournaise. In such an evolution, sills act as detachment planes, restoring the extensional stress field (Famin and Michon, 2010; Chaput et al., 2014a, 2014b).

Following the model of Chaput et al. (2014a), we tentatively interpret the subvertical dyke injections along the summit and outer rift zones and the sill intrusions below the eastern flank as controlled by cycles of stress permutations. Each cycle starts with dyke injections along the summit and outer rift zone in an extensional stress field, reducing the deviatoric stress until a switch of the axes of principal stresses, and ends with shallow ( $1 \mathrm{~km}$ depth; Froger et al., 2015) sill intrusions below the eastern flank. The flank lateral destabilisation restores the extensional stress field and initiates a new cycle of stress permutations. In such a process, sill-related flank movements strongly control subsequent magma intrusions along the outer rift zones, as in February 2005 and December 2005 when magma injections clearly followed the boundary of the slid zone of January 2004 (Fig. 12). This evolution, a flank landslide controlling lateral dyke propagation along rift zones, is similar to that observed at Mount Etna during the 2002-2003 eruptions (Acocella et al., 2003; Neri et al., 2005), at much larger scale at Kilauea (Dieterich, 1988) and postulated for Tenerife (Walter et al., 2005a). However, the source and depth of the flank destabilisation differ between these volcanoes. At Mount Etna, flank landslide above the deep décollement thrust is encouraged by overpressure in the 4-6-km-deep magma chamber (Walter et al., 2005b). At Kilauea, spreading rooted at the base of the volcanic edifice is thought to result from the creep of dunites accumulated by magma differentiation (Clague and Denlinger, 1994; Denlinger and Morgan, 2014). Finally, we suggest that the eastward flank displacement of Piton de la Fournaise stems from shallow (1-2 km depth below the surface) sill intrusions below its eastern flank.

In consequence, the dynamics of the rift zones related to the deep plumbing systems is prominently controlled by the regional stress field whereas perturbations of the shallow (edifice) stress field govern that of the rift zones associated with the shallow system. This interpretation is consistent with the very low seismicity of the NE and SE rift zones.

\section{Concluding remarks}

The main results of this work can be summarised as follows:

- Mapping the eruptive fissures and the cinder cones built of the massif of Piton de la Fournaise allowed us to identify and constrain the geometry of the rift zones and quantify the cone volume. Furthermore, we defined a robust relationship between the cone volumes and those of the associated lava flows that enabled the quantification of the magma volume and magma flux emitted along these rift zones $\left(\sim 0.1-0.25 \mathrm{~m}^{3} \mathrm{~s}^{-1}\right.$ for the rift zones within the Enclos Fouqué, $\sim 4-7.3 \times 10^{-3} \mathrm{~m}^{3} \mathrm{~s}^{-1}$ for the NE and SE rift zones and $\sim 0.5-3.6 \times 10^{-3} \mathrm{~m}^{3} \mathrm{~s}^{-1}$ for the NW-SE rift zone and the South Volcanic Zone).

- The 19-year-long database of VT seismic events recorded by the Piton de la Fournaise volcano observatory reveals the possible geometry of the plumbing system formed by i) a shallow seismic zone below the Enclos Fouqué central caldera and ii) two deep zones elongated in the $\mathrm{N} 120$ (intermediate) and N30-40 (deepest) and directions below the NW-SE rift zone cutting the western flank of the volcano. These seismically defined zones partly overlap with the cone distribution at the surface and are here interpreted as related to magma transfer and consequently image magma transfer from $35 \mathrm{~km}$ bsl (mantle lithosphere) to the surface. The parallel orientations of the deep plumbing system and of main known lithospheric faults suggest a strong control of the lithosphere inheritance on the deep magma paths.

- Moreover, we identified two rift zone types that differ in magma composition and magma flux. The weakly active NW-SE rift zone and possibly the South Volcanic Zone are associated with the deep plumbing system whereas the summit and outer rift zones are related to the shallow magma transfer. These two types of rift zones show striking similarities with the rift zones of the postshield and shield stages of Hawaiian volcanoes, respectively. As in Hawaii, the magma flux and the eruption frequency at Piton de la Fournaise are two orders of magnitude larger along the rift zones having a dynamics typical from the shield stage (the summit and outer rift zones) than along the "post-shield" rift zones (the NW-SE rift zone and the South Volcanic Zone). We propose that the coexistence of these two rift zone types at Piton de la Fournaise is governed by the existence of a regional extensional stress field, which controls the dynamics of the NW-SE rift zone and the South Volcanic Zone, and by a shallow stress field. The shallow stress field frequently evolves, thanks to the effects of magma overpressure and flank displacement, and consequently regulates the dynamics along the summit and outer rift zones.

- Finally, despite differences (e.g. geological context and structure) between Etna, Piton de la Fournaise, and Hawaiian volcanoes, eruptions involving magmas from the deep and shallow levels of the plumbing systems are rare, scattered, voluminous for the former and frequent and restricted to the summit or along narrow rift zones for the latter. We tentatively propose that as for Piton de la Fournaise, the regional stress field acting on Etna and Hawaiian volcanoes is an important parameter in the control of the magma transfer along the deep plumbing system whereas the dynamics of their summit system is governed by shallow stress variations (above 5-10 km bsl) due to edifice deformation and magma transfers.

\section{Acknowledgement}

This work has been funded by the Université de La Réunion, the Institut de Physique du Globe de Paris, the Préfecture of La Réunion and the MEEDDAT (Ministère de l'Ecologie, du Développement Durable et de l'Energie). The manuscript greatly benefited from the thourough reviews of Marco Neri and Jean-François Lénat. IPGP contribution 3658.

\section{References}

Acocella, V., Neri, M., 2003. What makes flank eruptions? The 2001 Etna eruption and its possible triggering mechanisms. Bull. Volcanol. 65, 517-529. http://dx.doi.org/10. 1007/s00445-003-0280-3.

Acocella, V., Behncke, B., Neri, M., D'Amico, S., 2003. Link between major flank slip and 2002-2003 eruption at Mt. Etna (Italy). Geophys. Res. Lett. 30 (24), 2286. http://dx. doi.org/10.1029/2003GL018642.

Aki, K., Ferrazzini, V., 2000. Seismic monitoring and modeling of an active volcano for prediction. J. Geophys. Res. 105, 16617-16640.

Albarède, F., Luais, B., Fitton, G., Semet, M., Kaminski, E., Upton, B., Bachèlery, P., Cheminée, J.L., 1997. The geochemical regimes of Piton de la Fournaise volcano (Réunion) during the last 530000 years. J. Pet. 38, 171-201. 
Bachèlery, P., 1981. Le Piton de la Fournaise (Ile de la Réunion). Etude volcanologique, structurale et pétrologique (Ph.D. Thesis), Université de Clermont-Ferrand, Clermont-Ferrand, France (215 pp.).

Bachèlery, P., Villeneuve, N., 2013. Hot spots and large igneous provinces. In: Shroder, J. Owen, L.A. (Eds.), Treatise on GeomorphologyTectonic Geomorphology vol. 5. Academic Press, San Diego, CA, pp. 193-233.

Bachèlery, P., Blum, P.A., Cheminée, J.-L., Chevallier, L., Gaulon, R., Girardin, N., Jaupart, C. Lalanne, F., Le Mouel, J.L., Ruegg, J.C., Vincent, P., 1982. Eruption at Le Piton de la Fournaise volcano on 3 February 1981. Nature 297, 395-397.

Battaglia, J., Aki, K., 2003. Location of seismic events and eruptive fissures on the Piton de la Fournaise volcano using seismic amplitudes. J. Geophys. Res. 108 (B8), 2364. http:// dx.doi.org/10.1029/2002JB002193.

Battaglia, J., Ferrazzini, V., Staudacher, T., Aki, K., Cheminée, J.-L., 2005a. Pre-eruptive migration of earthquakes at the Piton de la Fournaise volcano (Réunion Island). Geophys. J. Int. 161, 549-558. http://dx.doi.org/10.1111/j.1365-246X.2005.02606.x.

Battaglia, J., Aki, K., Staudacher, T., 2005b. Location of tremor sources and estimation of lava output using tremor source amplitude on the Piton de la Fournaise volcano: 2 Estimation of lava output. J. Volcanol. Geotherm. Res. 147, 291-308. http://dx.doi. org/10.1016/j.jvolgeores.2005.04.006.

Boivin, P., Bachèlery, P., 2009. Petrology of 1977 to 1998 eruptions of Piton de la Fournaise La Réunion Island. J. Volcanol. Geotherm. Res. 184 (1-2), 109-125. http://dx.doi.org/10. 1016/j.jvolgeores.2009.01.012.

Bonali, F.L., Corazzato, C., Tibaldi, A., 2011. Identifying rift zones on volcanoes: an example from La Réunion island, Indian Ocean. Bull. Volcanol. 73, 347-366. http://dx.doi.org/ 10.1007/s00445-010-0416-1.

Bosch, D., Blichert-Toft, J., Moynier, F., Nelson, B.K., Télouk, P., Gillot, P.-Y., Albarède, F. 2008. $\mathrm{Pb}, \mathrm{Hf}$ and $\mathrm{Nd}$ isotope compositions of the two Réunion volcanoes (Indian Ocean): a tale of two small-scale mantle. Earth Planet. Sci. Lett. 265, 748-765. http://dx.doi.org/10.1016/j.epsl.2007.11.018.

Bureau, H., Pineau, F., Metrich, N., Semet, M., Javoy, M., 1998a. A melt and fluid inclusion study of the gas phase at Piton de la Fournaise volcano (Reunion Island). Chem. Geol. $147,115-130$

Bureau, H., Métrich, N., Pineau, F., Semet, M., 1998b. Magma-conduit interaction at Piton de la Fournaise volcano (Réunion Island): a melt and fluid inclusion study. J. Volcanol. Geotherm. Res. 84, 39-60.

Bureau, H., Metrich, N., Semet, M.P., Staudacher, T., 1999. Fluid-magma decoupling in a hot-spot volcano. Geophys. Res. Lett. 26, 3501-3504.

Carracedo, J.C., 1994. The Canary Islands: an example of structural control on the growth of large oceanic-island volcanoes. J. Volcanol. Geotherm. Res. 60, 225-241.

Chadwick, W., Dieterich, J., 1995. Mechanical modeling of circumferential and radial dike intrusion on Galapagos Volcanoes. J. Volcanol. Geotherm. Res. 66, 37-52.

Chaput, M., Famin, V., Michon, L., 2014a. Deformation of basaltic shield volcanoes under cointrusive stress permutations. J. Geophys. Res. 119, 274-301.

Chaput, M., Pinel, V., Famin, V., Michon, L., Froger, J.-L., 2014b. Cointrusive shear displacement by sill intrusion in a detachment: a numerical approach. Geophys. Res. Lett. 41, 1937-1943. http://dx.doi.org/10.1002/2013GL058813.

Charvis, P., Laesanpura, A., Gallart, J., Hirn, A., Lépine, J.-C., De Voogd, B., Minshull, T.A Hello, Y., Pontoise, B., 1999. Spatial distribution of hotspot material added to the lithosphere under La Réunion, from wide-angle seismic data. J. Geophys. Res. 104, 2875-2893.

Chen, C.Y., Frey, F.A., 1983. Origin of Hawaiian tholeiite and alkalic basalt. Nature 302 785-789.

Chen, C.Y., Frey, F.A., 1985. Trace element and isotopic geochemistry of lavas from Haleakala volcano, East Maui, Hawaii: implications from the origin of Hawaiian basalts. J. Geophys. Res. 90, 8743-8768.

Chen, C.Y., Frey, F.A., Garcia, M.O., Dalrymple, G.B., Hart, S.R., 1991. The tholeiite to alkalic basalt transition at Haleakala Volcano, Maui, Hawaii. Contrib. Mineral. Petrol. 106, 183-200.

Chevallier, L., Bachèlery, P., 1981. Evolution structurale du volcan actif du Piton de la Fournaise, Ile de la Réunion-Océan indien occidental. Bull. Volcanol. 44 $723-741$

Chevallier, L., Vatin-Perignon, N., 1982. Volcano-structural evolution of Piton des Neiges, Reunion Island, Indian Ocean. Bull. Volcanol. 45, 285-298.

Clague, D.A., 1987. Hawaiian xenolith populations, magma supply rates, and development of magma chambers. Bull. Volcanol. 49, 577-587.

Clague, D., Denlinger, R., 1994. Role of olivine cumulates in destabilizing the flanks of Hawaiian volcanoes. Bull. Volcanol. 56, 425-434.

Clague, D.A., Sherrod, D.R., 2014. Growth and degradation of Hawaiian volcanoes. In: Poland, M.P., Takahashi, T.J., Landowski, C.M. (Eds.), Characteristics of Hawaiian volcanoes. U S Geol. Surv. Prof. Pap 1801, pp. 97-146 (chap. 3).

Clarke, D., Brenguier, F., Froger, J.L., Shapiro, N.M., Peltier, A., Staudacher, T., 2013. Timing of a large volcanic flank movement at Piton de la Fournaise Volcano using noise-based seismic monitoring and ground deformation measurements. Geophys J. Int. 195, 1132-1140. http://dx.doi.org/10.1093/gii/ggt276.

Colton, H.S., 1967. Cinder cones and lava flows. Museum Northern Arizona, Flagstaff, Arizona (58 pp.).

de Voogd, B., Palome, S., Hirn, A., Charvis, P., Gallart, J., Rousset, D., Danobeitia, J., Perroud, H., 1999. Vertical movements and material transport during hotspot activity: seismic reflection profiling offshore La Reunion. J. Geophys. Res. 104, 2855-2874.

Delaney, P.T., Denlinger, R.P., Lisowski, M., Miklius, A., Okubo, P.G., Okamura, A.T., Sako, M.K. 1998. Volcanic spreading at Kilauea, 1976-1996. J. Geophys. Res. 103, 18003-18023.

Denlinger, R.P., Morgan, J.K., 2014. Instability of Hawaiian volcanoes. In: Poland, M.P. Takahashi, T.J., Landowski, C.M. (Eds.), Characteristics of Hawaiian volcanoes. U S Geol. Surv. Prof. Pap 1801, pp. 149-176 (chap. 4).

Di Muro, A., Métrich, N., Vergani, D., Rosi, M., Armienti, P., Fougeroux, T., Deloule, E. Arienzo, I., Civetta, L., 2014. The shallow plumbing system of Piton de la Fournaise volcano (La Réunion Island, Indian Ocean) revealed by the major 2007 calderaforming eruption. J. Pet. 55, 1287-1315. http://dx.doi.org/10.1093/petrology/ egu025.

Dieterich, J.H., 1988. Growth and persistence of Hawaiian volcanic rift zones. J. Geophys. Res. 93, 4258-4270.

Dyment, J., 1991. Structure et évolution de la lithosphère océanique dans l'océan Indien: Apports des anomalies magnétiques (Ph.D. thesis), Univ. Strasbourg, Strasbourg, France (374 pp.)

Famin, V., Michon, L., 2010. Volcano destabilization by magma injections in a detachment. Geologija 38, 219-222.

Famin, V., Welsch, B., Okumura, S., Bachèlery, P., Nakashima, S., 2009. Three differentiation stages of a single magma at Piton de la Fournaise volcano (Reunion hot spot). Geochem. Geophys. Geosyst. 10, Q01007. http://dx.doi.org/10.1029/2008GC002015.

Favalli, M., Karátson, D., Mazzarini, F., Pareschi, M.T., Boschi, E., 2009. Morphometry of scoria cones located on a volcano flank: a case study from Mt. Etna (Italy), based on high-resolution LiDAR data. J. Volcanol. Geotherm. Res. 186, 320-330. http://dx. doi.org/10.1016/j.jvolgeores.2009.07.011.

Feigenson, M.D., Hofmann, A.W., Spera, F.J., 1983. Case studies on the origin of basalt II. The transition from tholeiitic to alkalic volcanism on Kohala volcano. Contrib. Mineral. Petrol. 84, 390-405.

Fernández, C., Casillas, R., García Navarro, E., Gutiérrez, M., Camacho, M.A., Ahijado, A., 2006. Miocene rifting of Fuerteventura (Canary Islands). Tectonics 25, TC6005. http://dx.doi.org/10.1029/2005TC001941.

Fiske, R.S., Jackson, E.D., 1972. Orientation and growth of Hawaiian volcanic rifts: the effect of regional structure and gravitational stress. Proc. R. Soc. London, Ser. A 329, 299-320.

Fontaine, F.R., Roult, G., Michon, L., Barruol, G., Di Muro, A., 2014. The 2007 eruptions and caldera collapse of the Piton de la Fournaise volcano (La Réunion Island) from tilt analysis at a single very broadband seismic station. Geophys. Res. Lett. 41, 2803-2811. http://dx.doi.org/10.1002/2014GL059691.

Fretzdorff, S., Haase, K.M., 2002. Geochemistry and petrology of lavas from the submarine flanks of Réunion Island western Indian Ocean): implications for magma genesis and the mantle source. Mineral. Petrol. 75, 153-184.

Froger, J.L., Fukushima, Y., Briole, P., Staudacher, T., Souriot, T., Villeneuve, N., 2004. The deformation field of the August 2003 eruption at Piton de la Fournaise, Reunion Island, mapped by ASAR interferometry. Geophys. Res. Lett. 31, L14601. http://dx. doi.org/10.1029/2004GL020479.

Froger, J.L., Famin, V., Cayol, V., Augier, A., Michon, L., Lénat, J.F., 2015. Time-dependent displacements during and after the April 2007 eruption of Piton de la Fournaise, revealed by interferometric data. J. Volcanol. Geotherm. Res. 296, 55-68.

Fukushima, Y., Cayol, V., Durand, P., 2005. Finding realistic dike models from interferometric synthetic aperture radar data: the February 2000 eruption at Piton de la Fournaise. J. Geophys. Res. 110, B03206. http://dx.doi.org/10.1029/2004JB003268.

Gallart, J., Driad, L., Charvis, P., Sapin, M., Hirn, A., Diaz, J., de Voogd, B., Sachpazi, M., 1999. Perturbation to the lithosphere along the hotspot track of La Réunion from an offshore-onshore seismic transect. J. Geophys. Res. 104, 2895-2908.

Gillot, P.Y., Nativel, P., 1989. Eruptive history of the Piton de la Fournaise volcano, Réunion island, Indian Ocean. J. Volcanol. Geotherm. Res. 36, 53-65.

Got, J.-L., Okubo, P., 2003. New insights into Kilauea's volcano dynamics brought by largescale relative relocation of microearthquakes. J. Geophys. Res. 108 (B7), 2337. http:// dx.doi.org/10.1029/2002JB002060.

Got, J.-L., Peltier, A., Staudacher, T., Kowalski, P., Boissier, P., 2013. Edifice strength and magma transfer modulation at Piton de la Fournaise volcano. J. Geophys. Res. 118, 5040-5057. http://dx.doi.org/10.1002/jgrb.50350.

Gripp, A.E., Gordon, R.G., 2002. Young tracks of hotspots and current plate velocities. Geophys. J. Int. 150, 321-361.

Guilbaud, M.-N., Siebe, C., Layer, P., Salinas, S., 2012. Reconstruction of the volcanic history of the Tacámbaro-Puruarán area (Michoacán, México) reveals high frequency of Holocene monogenetic eruptions. Bull. Volcanol. 74, 1187-1211. http://dx.doi.org/ 10.1007/s00445-012-0594-0.

Hibert, C., Mangeney, A., Grandjean, G., Shapiro, N.M., 2011. Slope instabilities in Dolomieu crater, Réunion Island: from seismic signals to rockfall characteristics. J. Geophys. Res. 116, F04032. http://dx.doi.org/10.1029/2011JF002038.

Hirn, A., Lépine, J., Sapin, M., Delorme, H., 1991. Episodes of pit-crater collapse documented by seismology at Piton de la Fournaise. J. Volcanol. Geotherm. Res. 47, 89-104.

Kereszturi, G., Geyer, A., Martí, J., Németh, K., Dóniz-Páez, F.J., 2013a. Evaluation of morphometry-based dating of monogenetic volcanoes-a case study from Bandas del Sur, Tenerife (Canary Islands). Bull. Volcanol. 75, 734. http://dx.doi.org/10.1007/ s00445-013-0734-1.

Kereszturi, G., Németh, K., Cronin, S.J., Agustín-Flores, J., Smith, I.E., Lindsay, J., 2013b. A model for calculating eruptive volumes for monogenetic volcanoes-implication for the Quaternary Auckland Volcanic Field, New Zealand. J. Volcanol. Geotherm. Res. 266, 16-33. http://dx.doi.org/10.1016/j.jvolgeores.2013.09.003.

Kervyn, M., Ernst, G., Carracedo, J.C., Jacobs, P., 2012. Geomorphometric variability of "monogenetic" volcanic cones: evidence from Mauna Kea, Lanzarote and experimental cones. Geomorphology 136, 59-75. http://dx.doi.org/10.1016/j.geomorph.2011. 04.009 .

Klein, F.W., Koyanagi, R.Y., Nakata, J.S. Tanigawa, W.R. 1987. The seismicity of Kilauea's magma system. In: Decker, R.W., Wright, T.L., Stauffer, T.H. (Eds.), Volcanism in Hawaii (2 vol). U S Geol. Surv. prof. pap. 1350(2), pp. 1019-1185 (chap. 43).

Kornprobst, J., Boivin, P., Lénat, J.F., Bachèlery, P., Bonneville, A., Dupont, P., Lecointre, J., Seidel, J.L. Thomas, P. Vincent, P.M. 1984 Le Piton de la Fournaise île de la Réunion. Colloque Prévision et Surveillance des Eruptions Volcaniques. (C.N.R.S.- I.N.A.G.). Clermont-Ferrand, pp. 75-82.

Krafft, M., Gerente, A., 1977a. L'activité du Piton de la Fournaise entre octobre 1972 et mai 1973. C. R. Acad. Sci., Paris Série D 284, 607-610. 
Krafft, M., Gerente, A., 1977b. L'activité du Piton de la Fournaise entre novembre 1975 et avril 1976. C. R. Acad. Sci, Paris Série D 284, 2091-2094.

Lacroix, A., 1936. Le volcan actif de l'île de la Réunion et ses produits. Gauthier-Villars, Paris (297 pp.).

Le Friant, A., Lebas, E., Clément, V., Boudon, G., Deplus, C., De Voogd, B., Bachèlery, P., 2011. A new model for the evolution of La Réunion volcanic complex from complete marine geophysical surveys. Geophys. Res. Lett. 38, L09312. http://dx.doi.org/10. 1029/2011GL047489.

Lee, W.H.K., Lahr, J.C., 1975. HYPO71 (revised): a computer program for determining hypocenter, magnitude, and first motion pattern of local earthquakes. U S Geol. Surv. Open File ReportUS Geol. Surv, Washington, DC, pp. 75-311.

Lénat, J.-F., Bachèlery, P., Bonneville, A., Tarits, P., Cheminée, J.-L., Delorme, H., 1989. The December 4, 1983 to February 18, 1984 eruption of Piton de la Fournaise (La Reunion, Indian Ocean): description and interpretation. J. Volcanol. Geotherm. Res. 36, 87-112.

Lénat, J.F., Bachèlery, P., Desmulier, F., 2001a. Genèse du champ de lave de l'Enclos Fouqué; une éruption d'envergure exceptionnelle du Piton de la Fournaise (Réunion) au 18e siècle. Bull. Soc. Geol. Fr. 172, 177-188.

Lénat, J., Gibert-Malengreau, B., Galdeano, A., 2001b. A new model for the evolution of the volcanic island of Réunion (Indian Ocean). J. Geophys. Res. 106, 8645-8663.

Lénat, J.-F., Bachèlery, P., Merle, O., 2012. Anatomy of Piton de la Fournaise volcano (La Réunion, Indian Ocean). Bull. Volcanol. 74, 1945-1961. http://dx.doi.org/10.1007/ s00445-012-0640-y.

Lipman, P.W., Calvert, A.T., 2011. Early growth of Kohala volcano and formation of long Hawaiian rift zones. Geologija 39, 659-662. http://dx.doi.org/10.1130/G31929.1.

Lipman, P.W., Sisson, T.W., Coombs, M.L., Calvert, A., Kimura, J.-I., 2006. Piggyback tectonics: long-term growth of Kilauea on the south flank of Mauna Loa. J. Volcanol. Geotherm. Res. 151, 73-108. http://dx.doi.org/10.1016/j.jvolgeores.2005.07.032.

Liuzzo, M., Giudice, G., Di Muro, A., Ferrazzini, V., Michon, L., 2014. New observational evidence of $\mathrm{CO} 2$ degassing anomalies on the Piton de la Fournaise and the relationship between seismotectonic structures and CO2 flux from the soil. Geophys. Res. Abstr. 16 (EGU2014-2444-1)

Longpré, M.-A., Staudacher, T., Stix, J., 2007. The November 2002 eruption at Piton de la Fournaise volcano, La Réunion Island: ground deformation, seismicity, and pit crater collapse. Bull. Volcanol. 69, 511-525. http://dx.doi.org/10.1007/s00445-006-0087-0.

López, C., Blanco, M.J., Abella, R., Brenes, B., Cabrera Rodríguez, V.M., Casas, B., Domínguez Cerdeña, I., Felpeto, A., de Villalta, M.F., del Fresno, C., García, O., García-Arias, M.J., García-Cañada, L., Gomis Moreno, A., et al., 2012. Monitoring the volcanic unrest of El Hierro (Canary Islands) before the onset of the 2011-2012 submarine eruption. Geophys. Res. Lett. 39, L13303. http://dx.doi.org/10.1029/2012GL051846.

MacDonald, G.A., 1972. Volcanoes. Prentice-Hall Inc Englewood Cliffs, New Jersey (510 pp.).

Marty, B., Meynier, V., Nicolini, E., Griesshaber, E., Toutain, J.P., 1993. Geochemistry of gas emanations: a case study of the Réunion Hot Spot, Indian Ocean. Appl. Geochem. 8, 141-152.

Massin, F., 2009. Transferts et stockages magmatiques au Piton de la Fournaise (Ph.D. thesis), Université de La Réunion, Saint-Denis, France (176 pp.).

Massin, F., Ferrazzini, V., Bachèlery, P., Nercessian, A., Duputel, Z., Staudacher, T., 2011. Structures and evolution of the plumbing system of Piton de la Fournaise volcano inferred from clustering of 2007 eruptive cycle seismicity. J. Volcanol. Geotherm. Res. 202, 96-106. http://dx.doi.org/10.1016/j.jvolgeores.2011.01.008.

McDougall, I., 1971. The geochronology and evolution of the young volcanic island of Réunion, Indian Ocean. Geochim. Cosmochim. Acta 35, 261-288.

McNutt, S.R., 2005. Volcanic seismology. Annu. Rev. Earth Planet. Sci. 33, 461-491. http:// dx.doi.org/10.1146/annurev.earth.33.092203.122459.

Menard, H.W., McNutt, M., 1982. Evidence for and consequences of thermal rejuvenation. J. Geophys. Res. 87, 8570-8580.

Michon, L., Saint-Ange, F., Bachèlery, P., Villeneuve, N., Staudacher, T., 2007. Role of the structural inheritance of the oceanic lithosphere in the magmato-tectonic evolution of Piton de la Fournaise volcano (La Reunion Island). J. Geophys. Res. 112, B04205. http://dx.doi.org/10.1029/2006JB004598.

Michon, L., Cayol, V., Letourneur, L., Peltier, A., Villeneuve, N., Staudacher, T., 2009. Edifice growth, deformation and rift zone development in basaltic setting: insights from Piton de la Fournaise shield volcano (Reunion Island). J. Volcanol. Geotherm. Res. 184, 14-30. http://dx.doi.org/10.1016/j.jvolgeores.2008.11.002.

Michon, L., Di Muro, A., Villeneuve, N., Saint-Marc, C., Fadda, P., Manta, F., 2013. Explosive activity of the summit cone of Piton de la Fournaise volcano (La Réunion island): historical and geological review. J. Volcanol. Geotherm. Res. 263, 117-133. http:// dx.doi.org/10.1016/j.jvolgeores.2013.06.012.

Montgomery-Brown, E.K., Sinnett, D.K., Larson, K.M., Poland, M.P., Segall, P., Miklius, A. 2011. Spatiotemporal evolution of dike opening and décollement slip at Kīlauea Volcano, Hawai'i. J. Geophys. Res. 116, B03401. http://dx.doi.org/10.1029/2010JB007762.

Moran, S.C., 2003. Multiple seismogenic processes for high-frequency earthquakes at Katmai National Park, Alaska: evidence from stress tensor inversions of fault-plane solutions. Bull. Seismol. Soc. Am. 93, 94-108.

Morandi, A., Principe, C., Di Muro, A., Leroi, G., Michon, L., Bachèlery, P., 2015. Pre-historic explosive activity at Piton de la Fournaise volcano. In: Bachèlery, P., Lénat, J.-F., Di Muro, A., Michon, L. (Eds.), Active Volcanoes of the Southwest Indian Ocean: Piton de la Fournaise and KarthalaActive Volcanoes of the World. Springer-Verlag, Berlin and Heidelberg (in press)

Morgan, J.K., Moore, G.F., Clague, D.A., 2003. Slope failure and volcanic spreading along the submarine south flank of Kilauea volcano, Hawaii. J. Geophys. Res. 108 (B9), 2415. http://dx.doi.org/10.1029/2003JB002411.

Müller, R.D., Royer, J.-Y., Lawver, L.A., 1993. Revised plate motions relative to the hotspots from combined Atlantic and Indian Ocean hotspot tracks. Geologija $21,275-278$.
Muller, J.R., Ito, G., Martel, S.J., 2001. Effects of volcano loading on dike propagation in an elastic half-space. J. Geophys. Res. 106, 11101-11113.

Nercessian, A., Hirn, A., Lépine, J.-C., Sapin, M., 1996. Internal structure of Piton de la Fournaise volcano from seismic wave propagation and earthquake distribution. J. Volcanol. Geotherm. Res. 70, 123-143.

Neri, M., Acocella, V., Behncke, B., 2004. The role of the Pernicana Fault System in the spreading of Mt. Etna (Italy) during the 2002?2003 eruption. Bull. Volcanol. 66 417-430. http://dx.doi.org/10.1007/s00445-003-0322-x.

Neri, M., Acocella, V., Behncke, B., Maiolino, V., Ursino, A., Velardita, R., 2005. Contrasting triggering mechanisms of the 2001 and 2002-2003 eruptions of Mount Etna (Italy). J. Volcanol. Geotherm. Res. 144, 235-255. http://dx.doi.org/10.1016/j.jvolgeores. 2004.11.025.

Neri, M., Acocella, V., Behncke, B., Giammanco, S., Mazzarini, F., Rust, D., 2011. Structural analysis of the eruptive fissures at Mount Etna (Italy). Ann. Geophys. 54, 464-479. http://dx.doi.org/10.4401/ag-5332.

Patanè, D., Cocina, O., Falsaperla, S., Privitera, E., Spampinato, S., 2004. Mt. Etna volcano: a seismological frame work. In: Calvari, S., Bonaccorso, A., Coltelli, M., Del Negro, C., Falsaperla, S. (Eds.), The Mt. Etna Volcano. AGU Monograph, Washington, D.C., pp. 147-165.

Patanè, D., Aiuppa, A., Aloisi, M., Behncke, B., Cannata, A., Coltelli, M., Di Grazia, G., Gambino, S., Gurrieri, S., Mattia, M., Salerno, G., 2013. Insights into magma and fluid transfer at Mount Etna by a multiparametric approach: a model of the events leading to the 2011 eruptive cycle. J. Geophys. Res. 118, 3519-3539. http://dx.doi.org/10. 1002 /jgrb.50248.

Peltier, A., Staudacher, T., Bachèlery, P., 2007. Constraints on magma transfers and structures involved in the 2003 activity at Piton de La Fournaise from displacement data. Journal of Geophysical Research 112. http://dx.doi.org/10.1029/2006JB004379.

Peltier, A., Famin, V., Bachèlery, P., Cayol, V., Fukushima, Y., Staudacher, T., 2008. Cyclic magma storages and transfers at Piton de La Fournaise volcano (La Réunion hotspot) inferred from deformation and geochemical data. Earth Planet. Sci. Lett. 270 180-188. http://dx.doi.org/10.1016/j.epsl.2008.02.042.

Peltier, A., Bachèlery, P., Staudacher, T., 2009. Magma transport and storage at Piton de La Fournaise (La Réunion) between 1972 and 2007: a review of geophysical and geochemical data. J. Volcanol. Geotherm. Res. 184, 93-108. http://dx.doi.org/10.1016/j. jvolgeores.2008.12.008.

Peterson, D.W., Moore, R.B., 1987. Geologic history and evolution of geological concepts, island of Hawaii. In: Decker, R.W., Wright, T.L., Stauffer, T.H. (Eds.), Volcanism in Hawaii (2 vol). U S Geol. Surv. prof. pap. 1350(1), pp. 149-189 (chap. 7).

Pietruszka, A.J., Hauri, E.H., Blichert-Toft, J., 2009. Crustal contamination of mantle-derived magmas within Piton de la Fournaise Volcano, Réunion Island. J. Pet. 50, 661-684. http://dx.doi.org/10.1093/petrology/egp016.

Porter, S.C., 1972. Distribution, morphology, and size frequency of cinder cones on Mauna Kea volcano, Hawaii. Geol. Soc. Am. Bull. 83, 3607-3612.

Prôno, E., Battaglia, J., Monteiller, V., Got, J.-L., Ferrazzini, V., 2009. P-wave velocity structure of Piton de la Fournaise volcano deduced from seismic data recorded between 1996 and 1999. J. Volcanol. Geotherm. Res. 184, 49-62. http://dx.doi.org/ 10.1016/j.jvolgeores.2008.12.009.

Ranalli, G., Murphy, D.C., 1987. Rheological stratification of the lithosphere. Tectonophysics $132,281-295$.

Riedel, C., Ernst, G.G.J., Riley, M., 2003. Controls on the growth and geometry of pyroclastic constructs. J. Volcanol. Geotherm. Res. 127, 121-152. http://dx.doi.org/10.1016/ S0377-0273(03)00196-3.

Roult, G., Peltier, A., Taisne, B., Staudacher, T., Ferrazzini, V., Di Muro, A., the OVPF team, 2012. A new comprehensive classification of the Piton de la Fournaise activity spanning the 1985-2010 period. Search and analysis of short-term precursors from a broad-band seismological station. J. Volcanol. Geotherm. Res. 241-242, 78-104 http://dx.doi.org/10.1016/j.jvolgeores.2012.06.012.

Ryan, M.P., 1988. The mechanics and three-dimensional internal structure of active magmatic systems: Kilauea volcano, Hawaii. J. Geophys. Res. 93, 4213-4248.

Salvany, T., Lahitte, P., Nativel, P., Gillot, P.-Y., 2012. Geomorphic evolution of the Piton des Neiges volcano (Réunion Island, Indian Ocean): competition between volcanic construction and erosion since 1.4 Ma. Geomorphology 136, 132-147. http://dx.doi. org/10.1016/j.geomorph.2011.06.009.

Schlich, R., Fondeur, C., 1974. Anomalies magnétiques crétacées dans le bassin des Mascareignes (Océan Indien). CR Acad. Sci. Paris 278 (B), 541-544.

Shamberger, P.J., Hammer, J.E., 2006. Leucocratic and gabbroic xenoliths from Hualala Volcano, Hawai'i. J. Pet. 47, 1785-1808. http://dx.doi.org/10.1093/petrology/egl027.

Sicali, S., Barbano, M.S., D'Amico, S., Azzaro, R., 2014. Characterization of seismicity at Mt Etna volcano (Italy) by inter-event time distribution. J. Volcanol. Geotherm. Res. 270 1-9. http://dx.doi.org/10.1016/j.jvolgeores.2013.11.011.

Siniscalchi, A., Tripaldi, S., Neri, M., Balasco, M., Romano, G., Ruch, J., Schiavone, D., 2012. Flank instability structure of Mt. Etna inferred by a magnetotelluric survey. J. Geophys. Res. 117, B03216. http://dx.doi.org/10.1029/2011JB008657.

Staudacher, T., Allègre, C.J., 1993. Ages of the second caldera of Piton de la Fournaise volcano (Réunion) determined by cosmic ray produced ${ }^{3} \mathrm{He}$ and ${ }^{21} \mathrm{Ne}$. Earth Planet Sci. Lett. 119, 395-404

Staudacher, T., Peltier, A., Ferrazzini, V., Di Muro, A., Boissier, P., Catherine, P., Kowalski, P., Lauret, F., 2015. Fifteen years of intense eruptive activity (1998-2013) at Piton de La Fournaise volcano (La Réunion): a review. In: Bachèlery, P., Lénat, J.-F., Di Muro, A Michon, L. (Eds.), Active Volcanoes of the Southwest Indian Ocean: Piton de la Fournaise and KarthalaActive Volcanoes of the World. Springer-Verlag, Berlin and Heidelberg (in press).

Tarasewicz, J., White, R.S., Woods, A.W., Brandsdóttir, B., Gudmundsson, M.T., 2012. Magma mobilization by downward-propagating decompression of the Eyjafjallajökull volcanic plumbing system. Geophys. Res. Lett. 39, L19309. http://dx.doi.org/10.1029/ 2012GL053518. 
Tinard, P., 2007. Caractérisation et modélisation des déplacements du sol associés à l'activité volcanique du Piton de la Fournaise, île de La Réunion, à partir de données interférométriques Août 2003 - Avril 2007: (Ph.D. Thesis), Université Blaise Pascal, Clermont-Ferrand, p. 334 (http://tel.archives-ouvertes.fr/action/open_file.php?url= http://tel.archives-ouvertes.fr/docs/00/27/15/39/PDF/PhD_Tinard.pdf\&docid=271539).

Villeneuve, N., Bachèlery, P., 2006. Revue de la typologie des éruptions au Piton de La Fournaise, processus et risques volcaniques associés. Cybergeo: Eur. J. Geogr. http:// dx.doi.org/10.4000/cybergeo.2536 (http://cybergeo.revues.org/2536).

Wadge, G., 1977. The storage and release of magma on Mount Etna. J. Volcanol. Geotherm. Res. 2, 361-384.

Walker, G.P.L., 1993. Basaltic-volcano systems. Geol. Soc. Lond. Spec. Publ. 76, 3-38. http://dx.doi.org/10.1144/GSL.SP.1993.076.01.01.

Walker, G.P.L., 1999. Volcanic rift zones and their intrusion swarms. J. Volcanol. Geotherm. Res. 94, 21-34.

Walter, T.R., Troll, V.R., 2003. Experiments on rift zone evolution in unstable volcanic edifices. J. Volcanol. Geotherm. Res. 127, 107-120. http://dx.doi.org/10.1016/S03770273(03)00181-1.

Walter, T.R., Troll, V.R., Cailleau, B., Belousov, A., Schmincke, H.U., Amelung, F., Bogaard, P. 2005a. Rift zone reorganization through flank instability in ocean island volcanoes: an example from Tenerife, Canary Islands. Bull. Volcanol. 67, 281-291. http://dx.doi. org/10.1007/s00445-004-0352-z

Walter, T.R., Acocella, V., Neri, M., Amelung, F., 2005b. Feedback processes between magmatic events and flank movement at Mount Etna (Italy) during the 2002-2003 eruption. J. Geophys. Res. 110, B10205. http://dx.doi.org/10.1029/2005JB003688.

Watanabe, T., Masuyama, T., Nagaoka, K., Tahara, T., 2002. Analog experiments on magma-filled cracks: Competition between external stresses and internal pressure. Earth Planets Space 54, 1247-1262.

Wolfe, E.W., Wise, W.S., Dalrymple, G.B., 1997. The geology and petrology of Mauna Kea Volcano, Hawaii: a study of postshield volcanism. U. S. Geol. Surv. Prof. Pap. 1557, 129.

Wood, C.A., 1980. Morphometric evolution of cinder cones. J. Volcanol. Geotherm. Res. 7, 387-413.

Wright, T.L., Klein, F.W., 2006. Deep magma transport at Kilauea volcano, Hawaii. Lithos 87, 50-79. http://dx.doi.org/10.1016/j.lithos.2005.05.004.

Zecevic, M., De Barros, L, Bean, C.J. O'Brien, G.S., Brenguier, F., 2013. Investigating the source characteristics of long-period (LP) seismic events recorded on Piton de la Fournaise volcano, La Réunion. J. Volcanol. Geotherm. Res. 258, 1-11. http://dx.doi. org/10.1016/j.jvolgeores.2013.04.009. 